\title{
Ophioderma hendleri sp. nov. (Echinodermata: Ophiuroidea: Ophiodermatidae) and its congeners from the Eastern Pacific
}

\author{
Rebeca GRANJA-FERNÁNDEZ 1,*, Tania PINEDA-ENRÍQUEZ ${ }^{2}$, \\ Francisco Alonso SOLÍS-MARÍN ${ }^{3} \&$ Alfredo LAGUARDA-FIGUERAS ${ }^{4}$ \\ ${ }^{1}$ Laboratorio de Ecología Marina. Centro Universitario de la Costa, \\ Universidad de Guadalajara, 48280 Puerto Vallarta, Mexico. \\ ${ }^{2}$ Department of Biology, Division of Invertebrate Zoology, Florida Museum of \\ Natural History, University of Florida, Gainesville, 32611 Florida, USA. \\ ${ }^{2}$ Natural History Museum of Los Angeles County, \\ 900 Exposition Blvd., 90007 Los Angeles, California, USA. \\ ${ }^{3,4}$ Colección Nacional de Equinodermos “Ma. E. Caso Muñoz”, Laboratorio de Sistemática \\ y Ecología de Equinodermos, Instituto de Ciencias del Mar y Limnología (ICML), \\ Universidad Nacional Autónoma de Mexico (UNAM), 04510 Ciudad de Mexico, Mexico. \\ *Corresponding author: beckygranja@gmail.com \\ ${ }^{2}$ Email: tpinedae@gmail.com \\ ${ }^{3}$ Email: fasolis@cmarl.unam.mx \\ ${ }^{4}$ Email: laguarda@cmarl.unam.mx \\ $1 \odot$ https://orcid.org/0000-0001-7119-0567 \\ $3 \odot$ https://orcid.org/0000-0001-5729-3316 \\ ${ }^{1}$ urn:1sid:zoobank.org:author:07A4492E-1844-4CF6-92E3-1AB64F93ED6A \\ ${ }^{2}$ urn:lsid:zoobank.org:author:29C721AC-5981-485C-B257-C496113060EA \\ ${ }^{3}$ urn:lsid:zoobank.org:author:F15D1F27-12CE-442C-B379-0FCDE9F47663 \\ ${ }^{4}$ urn:lsid:zoobank.org:author:74871827-C811-42E4-A627-505B3CD91370
}

\begin{abstract}
The widespread Ophioderma hendleri sp. nov., from the Eastern Tropical Pacific (Mexico to Colombia) is distinguished from its congeners by having radial shields covered by granules, naked adoral shields, up to 11 arm spines, and by its brown and beige coloration. Ophioderma hendleri sp. nov. belongs to the group of species with naked adoral shields (i.e., O pentacanthum H.L. Clark, 1917, $O$. variegatum Lütken, 1856), and it has frequently been misidentified as $O$. panamense Lütken, 1859 or $O$. variegatum. Therefore, the main aim of the present work was to describe Ophioderma hendleri sp. nov. and differentiate it from its congeners. The original description of $O$. panamense was incomplete; thus, we provide a redescription. Due to the confusion in previous designations of its type material, we designate a lectotype and paralectotype of $O$. variegatum. Finally, we expand the distribution range of $O$. pentacanthum to Cocos Island, Costa Rica. With this work, the total number of valid species of Ophioderma Müller \& Troschel, 1840 in the world increases to 33 and in the Eastern Pacific to nine species.
\end{abstract}


Keywords. Brittle stars, lectotype, paralectotype, new distribution record, taxonomy.

Granja-Fernández R., Pineda-Enríquez T., Solís-Marín F.A. \& Laguarda-Figueras A. 2020. Ophioderma hendleri sp. nov. (Echinodermata: Ophiuroidea: Ophiodermatidae) and its congeners from the Eastern Pacific. European Journal of Taxonomy 729: 11-41 https://doi.org/10.5852/ejt.2020.729.1187

\section{Introduction}

Ophioderma Müller \& Troschel, 1840 is one of the 11 genera belonging to the family Ophiodermatidae Ljungman, 1867 (O'Hara et al. 2018), and it is characterized by a disc with granules and the presence of four genital slits in each interradius (Ziesenhenne 1955; Hendler et al. 1995). This genus is very common at shallow depths (intertidal to $300 \mathrm{~m}$, but most common down to $50 \mathrm{~m}$ ), mostly in tropical and subtropical waters. It is usually observed at turbulent sites or in high energy areas near breaking waves, and it is commonly associated with coral reefs, oyster reefs, seagrass beds, mangroves, beachrock platforms, shell, rubble, sand, mud, sponges and algae (Hendler et al. 1995). Ophiuroids are rarely harvested by humans; however, species of Ophioderma are sold as aquarium species (Stöhr et al. 2012).

According to the latest classification of the Ophiuroidea Gray, 1840, Ophioderma comprises a total of 32 living species, most of them distributed in the Gulf of Mexico and the Caribbean as well as in the Eastern Pacific (Stöhr et al. 2020a, 2020b). Specifically, a total of seven valid species inhabit the Eastern Pacific: Ophioderma panamense Lütken, 1859, O. pentacanthum H.L. Clark, 1917, O. peruanum PinedaEnríquez et al., 2013, O. sodipallaresi Caso, 1986, O. teres Lyman, 1860, O. vansyoci Hendler, 1996 and O. variegatum Lütken, 1856, in addition to O. teres var. unicolor H.L. Clark, 1940 which presents an unclear taxonomic status. All the species mentioned above are distributed in shallow waters (intertidal to $50 \mathrm{~m}$ depth; Solís-Marín et al. 2013; Pineda-Enríquez et al. 2013) except for O. pentacanthum, which has been collected below $100 \mathrm{~m}$ depth (H.L. Clark 1917).

The study of Ophioderma in the Eastern Pacific began in 1860, focusing mainly on taxonomic papers on conspicuous species such as $O$. panamense and O. teres (e.g., Nielsen 1932; Ziesenhenne 1955; Granja-Fernández et al. 2014), but in the case of less conspicuous species such as $O$. vansyoci or O. pentacanthum, few published works exist (H.L. Clark 1917; Ziesenhenne 1955; Hendler 1996; Hernández-Herrejón et al. 2010). The most important works about Ophioderma of the Eastern Pacific are Nielsen (1932), Ziesenhenne (1955), Pineda-Enríquez et al. (2013) and Granja-Fernández et al. (2014), who provided important descriptions, taxonomic keys and comments on the species, but none of them revised the type material.

Stöhr et al. (2009) mentioned that although there are many important morphological characters to separate the species of Ophioderma, these characters are often rather variable, which causes some difficulties for their identification. It is important to take into account that specimens (e.g., of $O$. panamense, $O$. pentacanthum and $O$. variegatum) in various scientific collections may have been misidentified (e.g., Caso 1951; Ziesenhenne 1955), because Ophioderma is highly cryptic (e.g., Stöhr et al. 2020b). Closer observations often reveal that these previously confused cryptic species differ by subtle differences, often in color pattern, or novel morphological characters, and differences in habitat preference or life history (Boissin et al. 2011). For these reasons, Ophioderma hendleri sp. nov. has been misidentified previously and confused with its congeners. Therefore, the aims of this work are: 1) to describe the new species $O$. hendleri sp. nov., 2) to redescribe $O$. panamense, 3 ) to designate a lectotype and paralectotype for $O$. variegatum, and finally, 4) to provide detailed descriptions, morphological characters, and photographs for each species used as a comparison between $O$. hendleri sp. nov., $O$. panamense, O. variegatum and O. pentacanthum. 


\section{Material and methods}

Ophioderma hendleri sp. nov. was collected between 2007 and 2016 on rocky and coral reefs, at different depths (intertidal to $37 \mathrm{~m}$ ) at localities on the Pacific coast of Mexico and Costa Rica. The animals were hand collected by scuba diving. All the collected ophiuroids were anesthetized using menthol buffered with seawater, to prevent autotomy; afterwards, all specimens were fixed and preserved in $70 \%$ ethanol.

Additionally, specimens of $O$. hendleri sp. nov., $O$. panamense, $O$. pentacanthum and $O$. variegatum, stored in different scientific collections, as well as type material, were examined and taxonomically reviewed.

These were housed at:

CE-UAM

CZA

EMU-UNAM

ICML-UNAM

ITBB

LACM

$\mathrm{MCZ}$

MHNMC-Makuriwa

MZUCR

NHMD

USNM

: Colección de Equinodermos de la Universidad Autónoma Metropolitana-Iztapalapa, Ciudad de Mexico, Mexico

: Colección de Zoología Acuática, Universidad Peruana Cayetana Heredia, Lima, Peru

: Colección Regional de Invertebrados Marinos del Laboratorio de Invertebrados Bentónicos de la Unidad Académica Mazatlán, Instituto de Ciencias del Mar y Limnología, Universidad Nacional Autónoma de Mexico (ICML-UNAM), Sinaloa, Mexico

: Colección Nacional de Equinodermos "Dra. Ma. Elena Caso Muñoz", ICML-UNAM, Ciudad de Mexico, Mexico

: Colección de Invertebrados del Instituto de Bahía de Banderas, Nayarit, Mexico

: Natural History Museum, Los Angeles County Museum, Los Angeles, United States

: Museum of Comparative Zoology, Harvard University, Cambridge, United States

: Museo de Historia Natural Marina de Colombia-Makuriwa, Instituto de Investigaciones Marinas y Costeras, Santa Marta, Colombia

: Museo de Zoología, Universidad de Costa Rica, San José, Costa Rica

: Natural History Museum of Denmark, University of Copenhagen, Copenhagen, Denmark

: Smithsonian National Museum of Natural History, Washington DC, United States

All the examined material is listed in the Supplementary material.

All the type specimens of the species in this work were photographed using an Olympus SZX16 stereo microscope with an adapted Nikon D750 camera or a Velab VE-S5 stereo microscope with an adapted Canon SX700-HS camera. Ossicles of some specimens from the type series of $O$. hendler $i$ sp. nov. and non-type specimens of $O$. panamense and $O$. variegatum were prepared by dissolving all soft tissue in undiluted bleach; dissociated ossicles were then mounted for scanning electron microscopy (SEM). All the microstructures were mounted on aluminum stubs, gold coated and examined in a Hitachi S-2460N SEM at the Laboratorio de Microscopía, Instituto de Biología, Universidad Nacional Autónoma de Mexico, Mexico. Individuals of $O$. pentacanthum were not disarticulated due to the low number of specimens.

The type specimens were measured with an electronic vernier scale. We followed Stöhr et al. (2012), Thuy \& Stöhr (2016) and Hendler (2018) on morphological terms, and O'Hara et al. (2018) for systematics. Valid names agree with Stöhr et al. (2020a). 


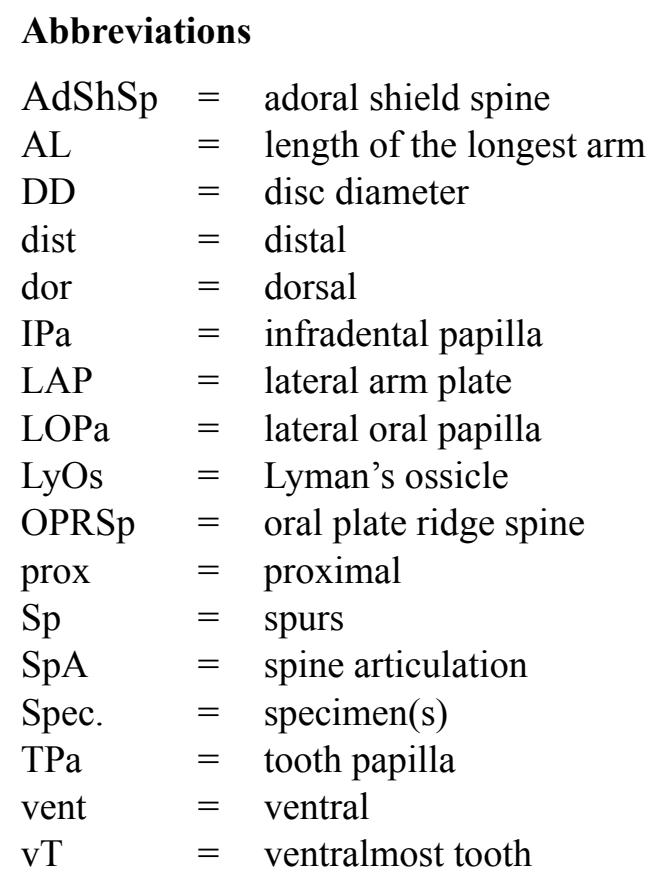

\section{Results}

Phylum Echinodermata Bruguière, 1791

Class Ophiuroidea Gray, 1840

Order Ophiacanthida O'Hara et al., 2017

Suborder Ophiodermatina Ljungman, 1867

Family Ophiodermatidae Ljungman, 1867

Genus Ophioderma Müller \& Troschel, 1840

Ophioderma hendleri sp. nov. urn:1sid:zoobank.org:act:3455BEAC-DF5D-460A-89A8-A70B9A080BB4

Figs $1-4,5 \mathrm{~A}-\mathrm{D}$; Table 1

Ophioderma sp. - Granja-Fernández et al. 2014: 135-137, fig. 7A-F; 2015a: 41-42; 2017: 172-175.

\section{Diagnosis}

Radial shields covered by granulation. Adoral shields naked, as long as broad. Up to 11 arm spines, dorsalmost the shortest and blunt, ventralmost the largest and robust. In vivo coloration, disc dark brown and mottled with small white spots, ventral margin beige and brown; arms dark brown with transverse white bands.

\section{Etymology}

This species is named after Dr. Gordon Hendler, an eminent ophiuroid taxonomist, curator of echinoderms at the Natural History Museum of Los Angeles County.

\section{Material examined}

\section{Holotype}

MEXICO • 1 spec.; Chipehua, Oaxaca, 16² $49.90^{\prime \prime}$ N, 95²1'33.70" W; 21 m; 5 Nov. 2011; R. Granja leg.; under rocks; ICML-UNAM 18315. 


\section{Paratypes}

COSTA RICA • 6 specs; Coco Island; 19-28 Feb. 1994; Gordon Hendler leg.; MZUCR-ECH 321.

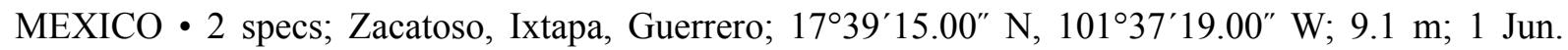
2012; R. Granja leg.; under rocks; ICML-UNAM 10582 • 1 spec.; Chahué, Oaxaca; $15^{\circ} 45^{\prime} 02.90^{\prime \prime}$ N, 96 $07^{\circ} 23.43^{\prime \prime} \mathrm{W}$; $6.5 \mathrm{~m}$; $14 \mathrm{Jan}$. 2017; R. Granja leg.; under rocks, $27^{\circ} \mathrm{C}$; ICML-UNAM $18316 \bullet 2$ specs; Tijera, Oaxaca; $15^{\circ} 41^{\prime} 15.12^{\prime \prime}$ N, 96 $26^{\prime} 31.47^{\prime \prime}$ W; 9 m; 29 Jan. 2016; D. Rangel and R. Granja leg.; under rocks, $27^{\circ} \mathrm{C}$; ICML-UNAM 18317 • 1 spec.; Frente a Llano Grande, Oaxaca; $16^{\circ} 14^{\prime} 30.26^{\prime \prime} \mathrm{N}$, 98 $27^{\prime} 04.64^{\prime \prime} \mathrm{W} ; 20 \mathrm{~m}$; $1 \mathrm{Feb} .2016$; Rebeca Granja leg.; sediment under rocks, $27^{\circ} \mathrm{C}$; ICML-UNAM 18318 • 1 spec.; La Jeringa, Cacaluta Island, Oaxaca; 1543'10.92" N, 9609'39.91" W; 9-14 m; 26 Jan. 2016; D.Rangel and R. Granja leg.; sediment under rocks; ICML-UNAM 18319 • 2 specs; Punta Lobos, Espíritu Santo Island, Gulf of California; 24²8'29.06" N, 110¹7'20.65" W; 15-17 m; 28 Oct. 2016; R. Granja leg.; under rocks, $28^{\circ} \mathrm{C}$; ICML-UNAM 18320 • 3 specs; San Diego Norte, Gulf of California; $25^{\circ} 12^{\prime} 15.48^{\prime \prime} \mathrm{N}, 110^{\circ} 41^{\prime} 41.64^{\prime \prime} \mathrm{W} ; 13 \mathrm{~m}$; 29 Oct. 2016; R. Granja leg.; under rocks, $29^{\circ} \mathrm{C}$; ICMLUNAM 18321 • 1 spec.; San Mateo Norte, Gulf of California; 2522'43.54" N, 110 59'34.26" W; 12 m; 31 Oct. 2016; R. Granja leg.; under rocks, $29^{\circ} \mathrm{C}$; ICML-UNAM $18322 \cdot 10$ specs; Isla San Diego, Gulf of California; $25^{\circ} 12^{\prime} 12.78^{\prime \prime} \mathrm{N}, 110^{\circ} 41^{\prime} 40.14^{\prime \prime} \mathrm{W} ; 10-11 \mathrm{~m}$; 31 Aug. 2008; F. Solís and Solís-Wolfowitz leg.; under rocks; ICML-UNAM 18323 • 5 specs; El Peruano, Guaymas, Sonora, Gulf of California;

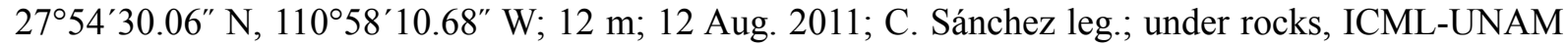
18324 - 1 spec.; La Lobera, Bahía de La Paz, Gulf of California; 24³6'56.39" N, 110²4’00.57" W; 7 m; 2 Mar. 2010; F. Solís leg.; under rocks, ICML-UNAM 18325 • 1 spec.; Isla Larga (estación Este), Marietas Islands; $20^{\circ} 41^{\prime} 08.00^{\prime \prime} \mathrm{N}, 105^{\circ} 34^{\prime} 00.00^{\prime \prime} \mathrm{W}$; 9 m; 22 Mar. 1996; F. Solís and C. Nepote leg.; under rocks; ICML-UNAM 18326 • 1 spec.; Los Islotes, Bahía de La Paz, Gulf of California; $24^{\circ} 35^{\prime} 00.00^{\prime \prime} \mathrm{N}$, $110^{\circ} 25^{\prime} 00.00^{\prime \prime} \mathrm{W} ; 18.3$ m; 28 Apr. 1997; H. Cortés leg.; sediment under rocks; ICML-UNAM 18327.

PANAMA • 2 specs; Panama; 24 Jun.-23 Jul. 1872; Hassler expedition leg.; MCZ OPH-116.

\section{Other material}

See: Supplementary material.

\section{Holotype description}

$\mathrm{DD}=14.8 \mathrm{~mm} ; 5 \mathrm{arms}, \mathrm{AL}=69.1 \mathrm{~mm}$. Disc flat, nearly circular. Dorsal disc densely covered by rounded, small granules, slightly separated from each other; granule density $113 \mathrm{~mm}^{-2}$. Granules at periphery of disc and on base of arms slightly larger than on central part of disc. Radial shields covered by granules (Fig. 1A). Interradii covered with granulation, similar to periphery and base of arms (Fig. 1B). Four genital slits in each interradius (Fig. 1B); proximal genital slits oval, in contact with distal part of oral shield and with $1^{\text {st }}$ LAP; distal genital slits rounded, elongated, placed between $5^{\text {th }}$ and $6^{\text {th }}$ arm segment and close to margin of disc, surrounded by granulation and numerous, elongated and imbricated scales next to side of lateral arm plates (Fig. 1B).

Oral shields slightly broader than long, rounded triangular, with convex obtuse proximal angle, straight to convex distal edge, obtuse lateral angles. Madreporite with central, circular, shallow depression, located in distal part of oral shield. Adoral shields naked, as long as broad, triangular and completely separated from each other. Jaws bear 8-9 oral papillae on each side: LyOs small, $2 \times$ as long as broad, angled upwards; AdShSp largest, rounded; $2^{\circ} \mathrm{AdShSp}$ elongated and narrow; LOPas 4-5 conical and pointed, slightly separated; IPa reduced, elongated and pointed; TPa pair at apex of jaw, elongated, robust and pointed, slightly separated. vT similar in shape and slightly larger than TPa. Four teeth: ventralmost broader than long, quadrangular but with rounded borders; dorsalmost pointed, slender and smallest. One OPRSp, large and pointed at each side, visible within buccal cavity. Granules covering oral plates and below adoral shields larger than those on dorsal disc and interradii (Fig. 1C-D). 


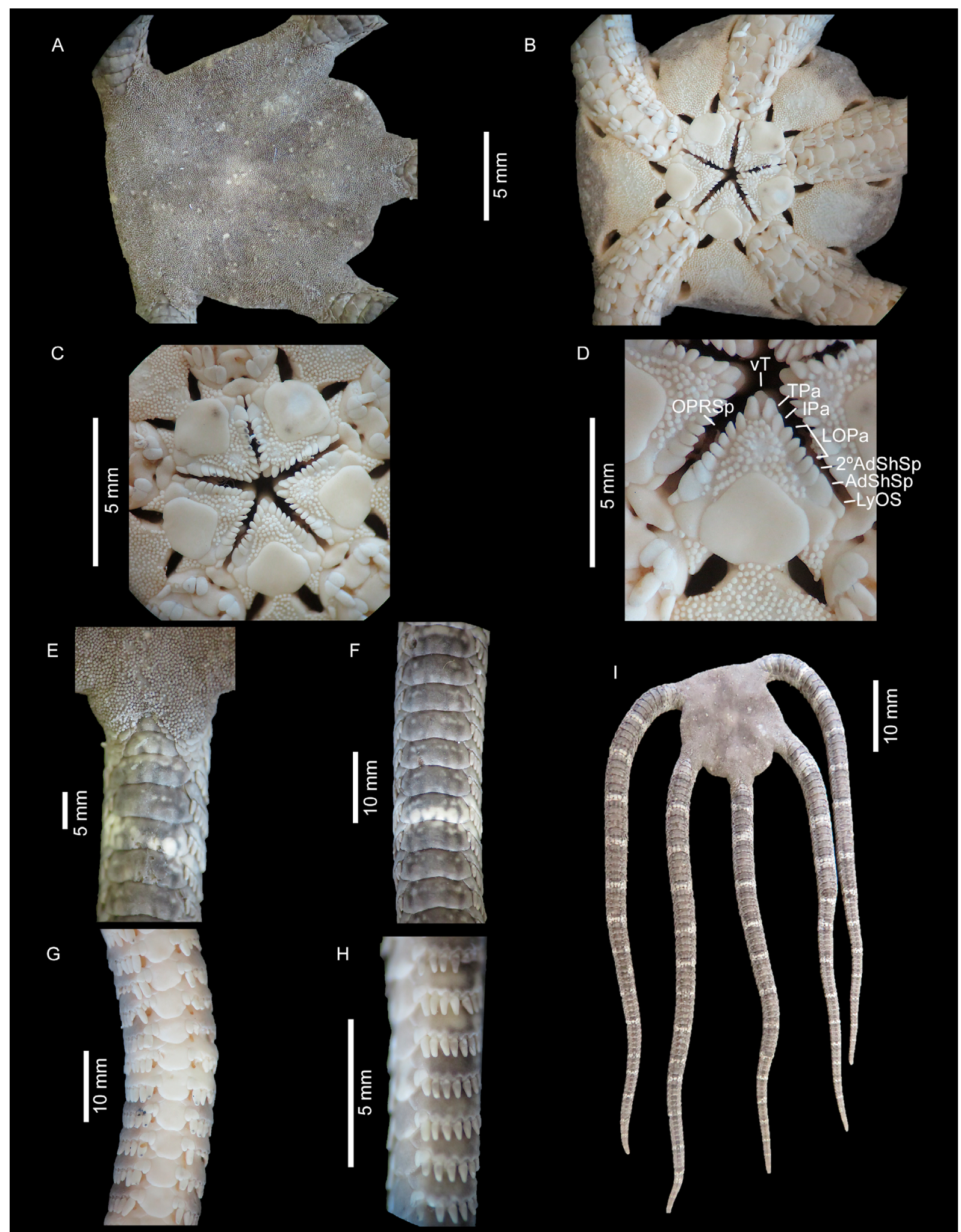

Fig. 1. Ophioderma hendleri sp. nov., holotype (ICML-UNAM 18315, DD = $14.8 \mathrm{~mm}$ ). A. Dorsal disc. B. Ventral disc. C. Mouth. D. Structures of a jaw (according to Hendler 2018). E. Basal dorsal arm. F. Dorsal arm. G. Ventral arm. H. Lateral arm plates and arm spines. I. Dorsal view. See Material and methods for abbreviations. 


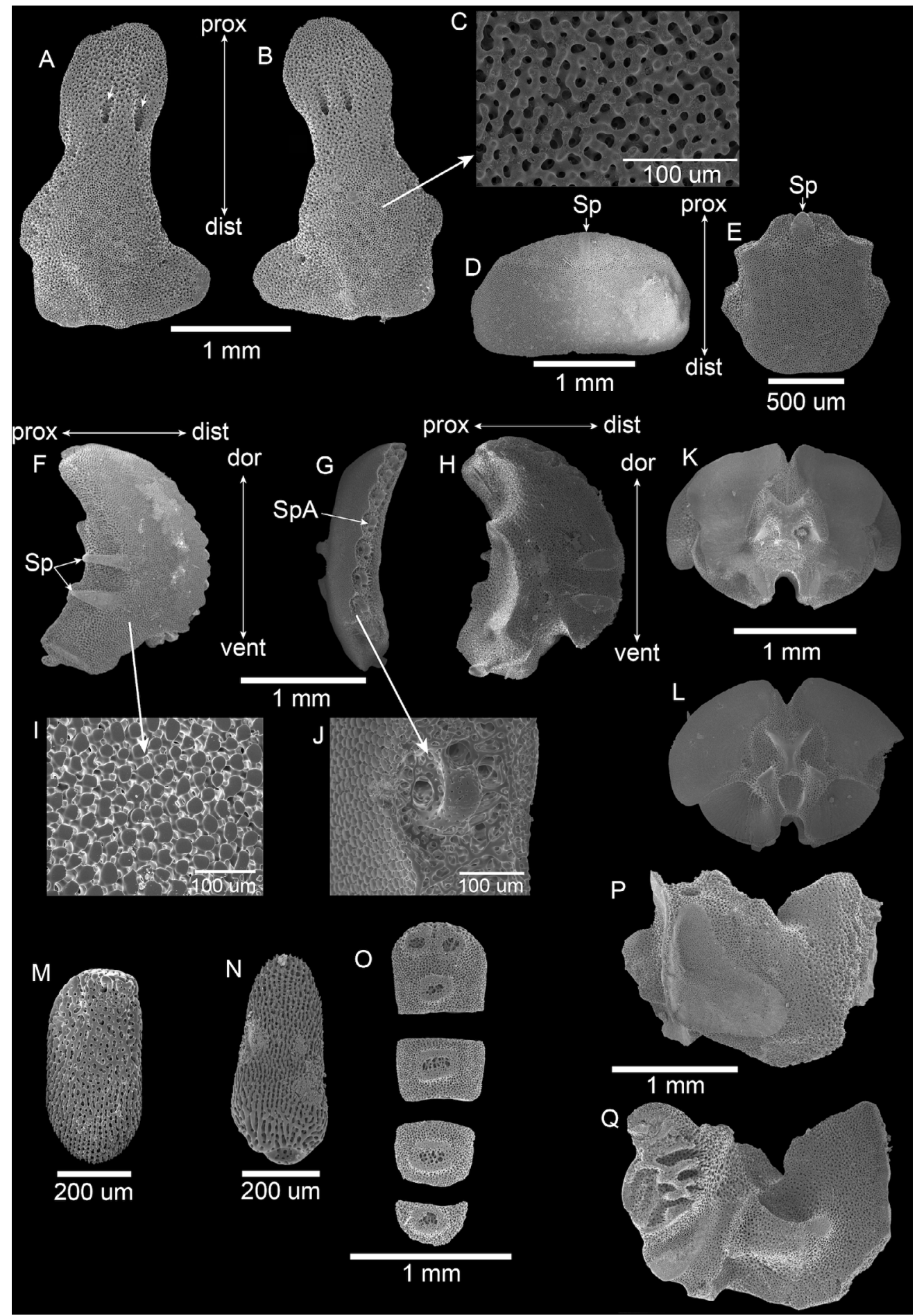

Fig. 2. SEM images of skeletal elements of Ophioderma hendleri sp. nov., paratype (ICML-UNAM 18323, DD $=15 \mathrm{~mm}$ ). A-B. Radial shield (external view), deepest pores marked with arrows. C. Center of the distal portion of the radial shield, open meshed pores. D. Dorsal arm plate, with one spur. E. Ventral arm plate, with one spur. F. Lateral arm plate, external face, with two spurs and one condyle. G. Lateral arm plate, lateral face, with spine articulations. H. Lateral arm plate, internal face. I. Outer surface of the LAP (F) with finely meshed and polygonal knobs. J. Spine articulations with a weak sigmoidal fold and tilted lobes. K. Arm vertebra, distal face. L. Arm vertebra, proximal face. M. Tentacle scale. N. Arm spine. O. Dental plate fragments. P. Oral plate, abradial face. Q. Oral plate, adradial face. 


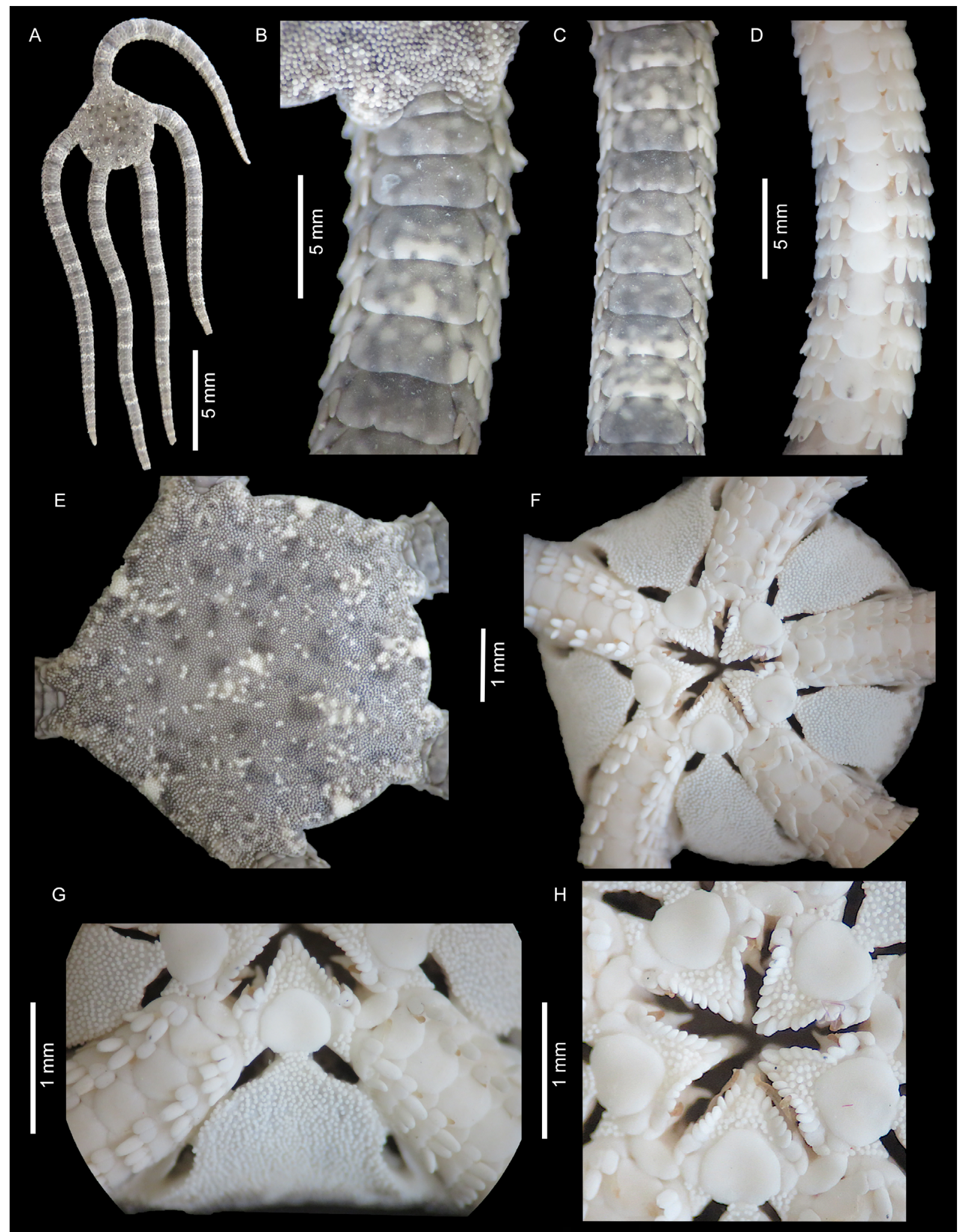

Fig. 3. Ophioderma hendleri sp. nov., paratype (ICML-UNAM 10582, DD = $4.8 \mathrm{~mm}$ ). A. Dorsal view. B. Basal dorsal arm. C. Dorsal arm. D. Ventral arm. E. Dorsal disc. F. Ventral disc. G. Interradii. H. Mouth. 

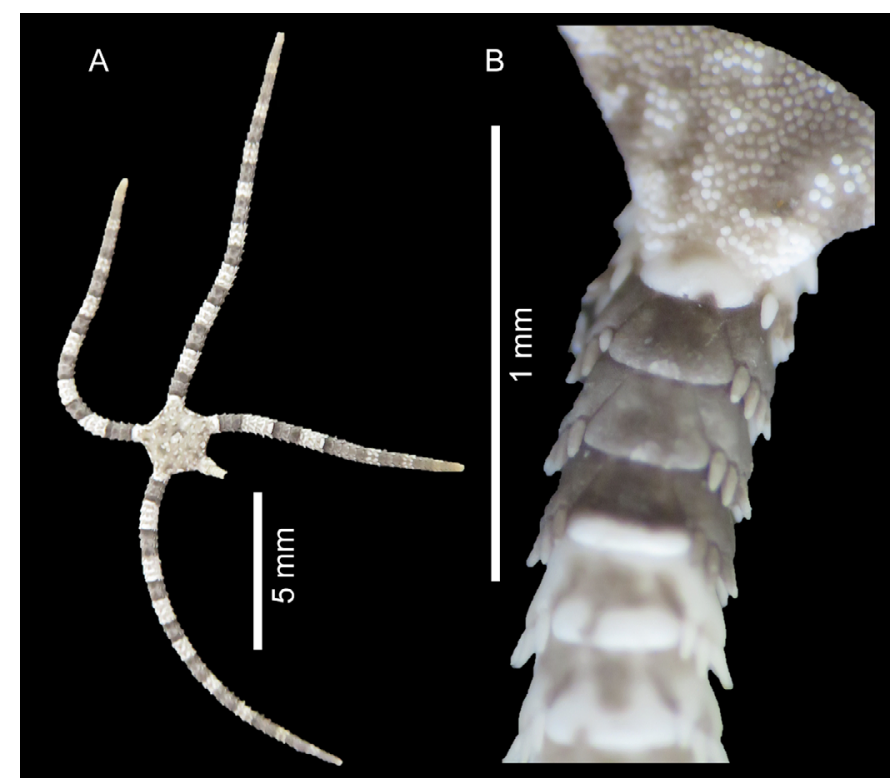

$E$

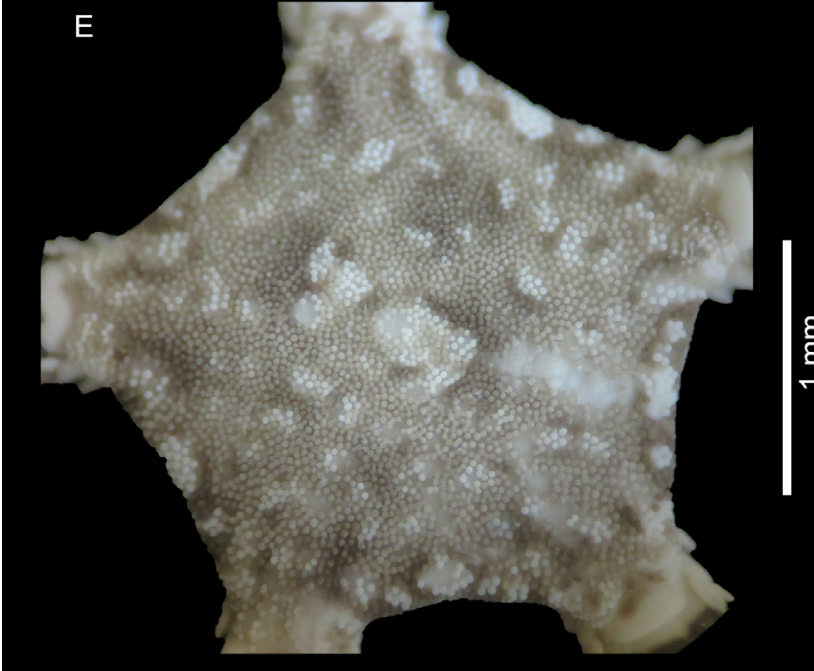

G

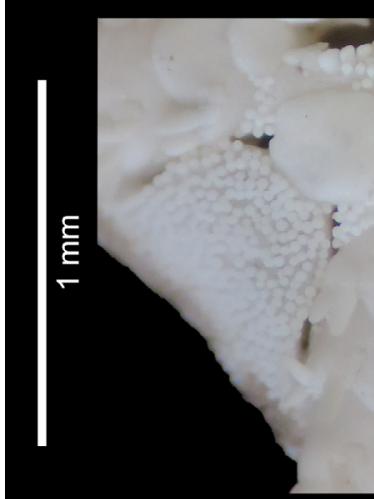

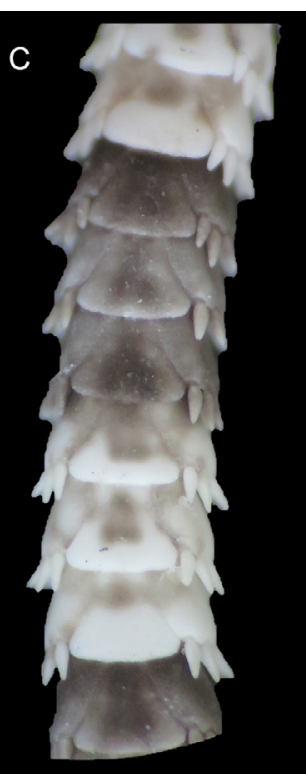
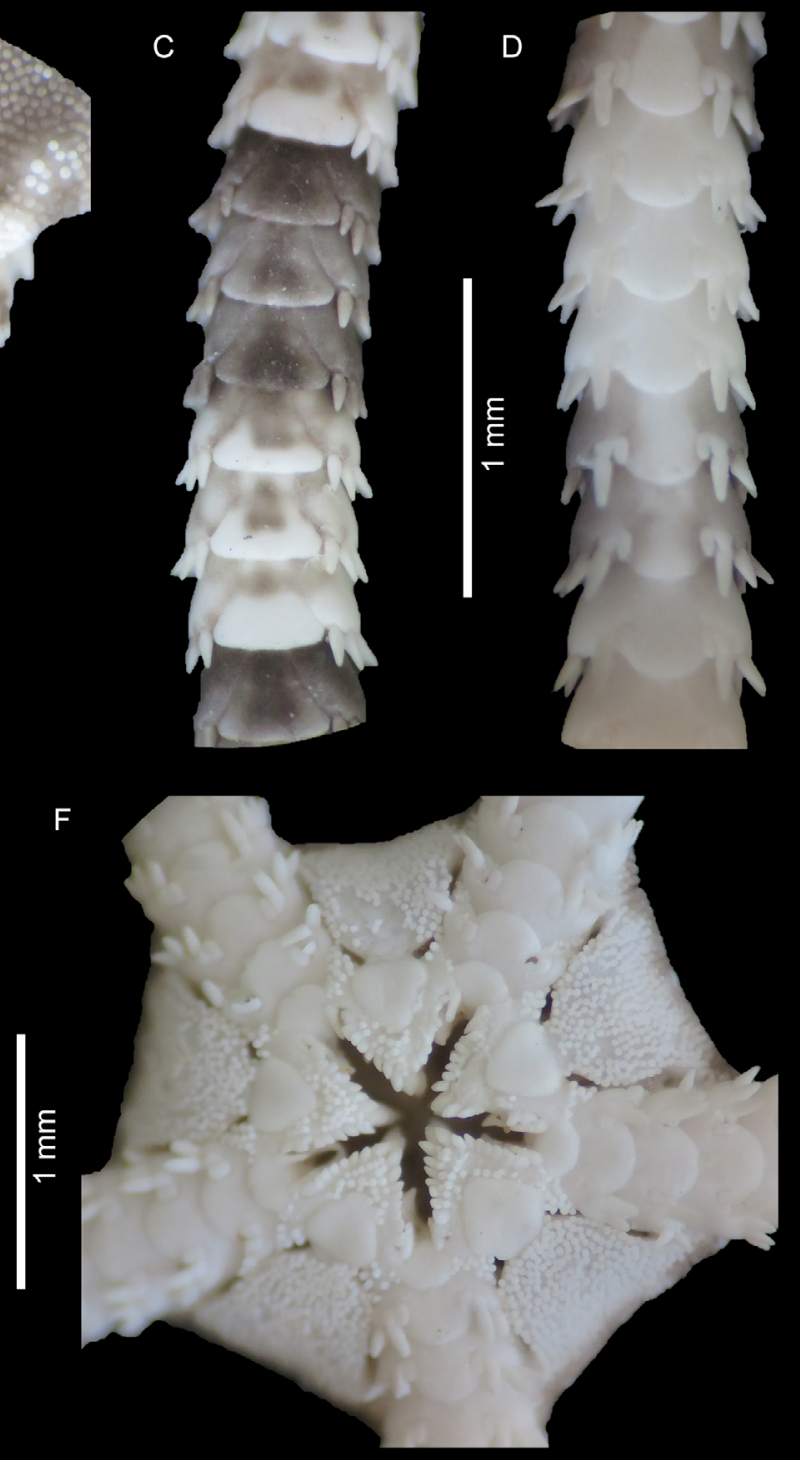

$\mathrm{H}$

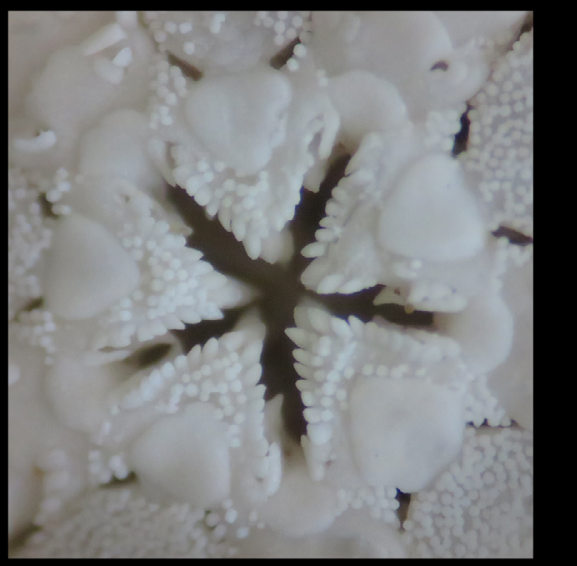

Fig. 4. Ophioderma hendleri sp. nov., paratype (ICML-UNAM 18319, DD = $2.2 \mathrm{~mm}$ ). A. Dorsal view. B. Basal dorsal arm. C. Dorsal arm. D. Ventral arm. E. Dorsal disc. F. Ventral disc. G. Interradii. H. Mouth. 

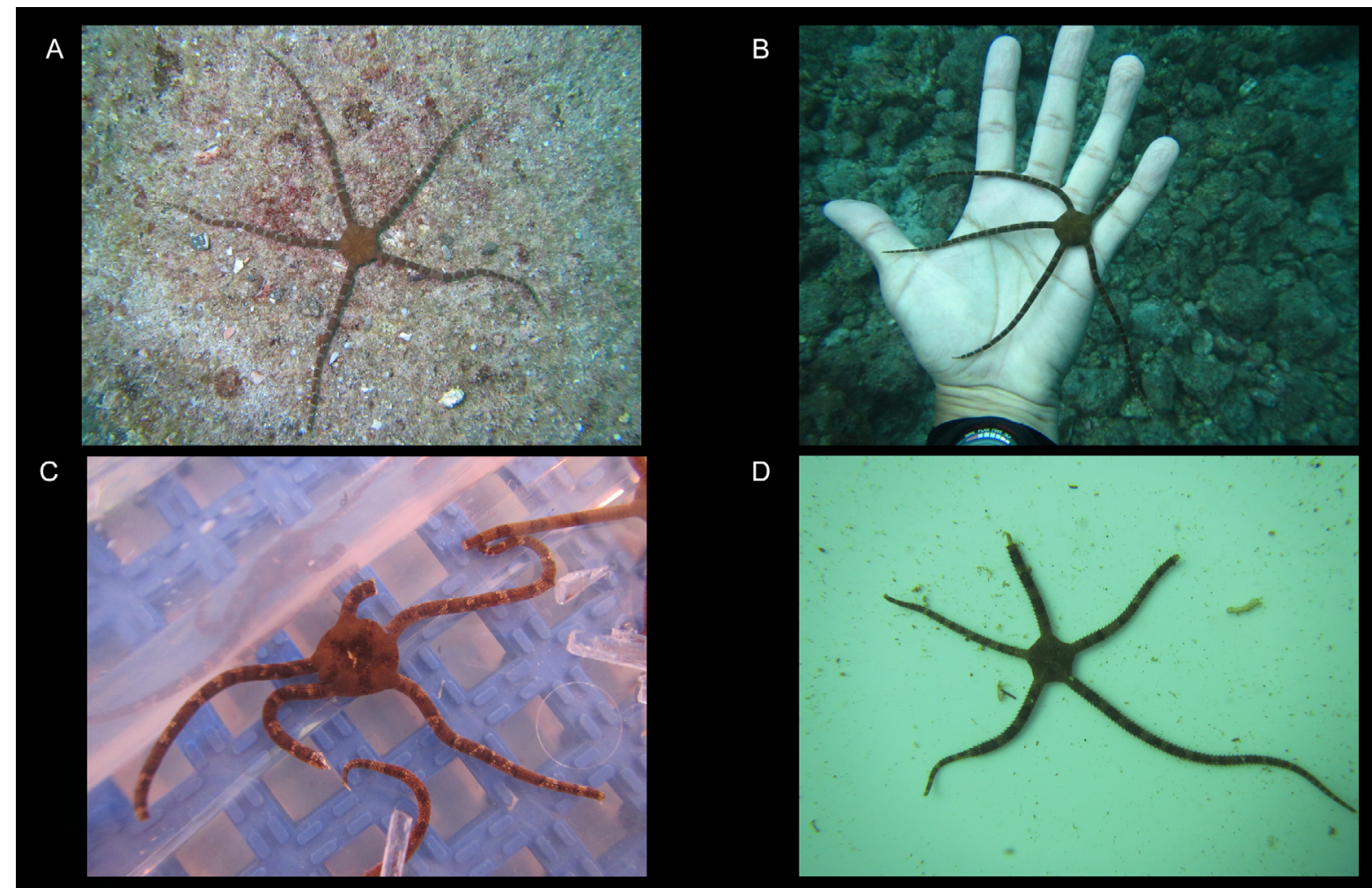

$\mathrm{D}$
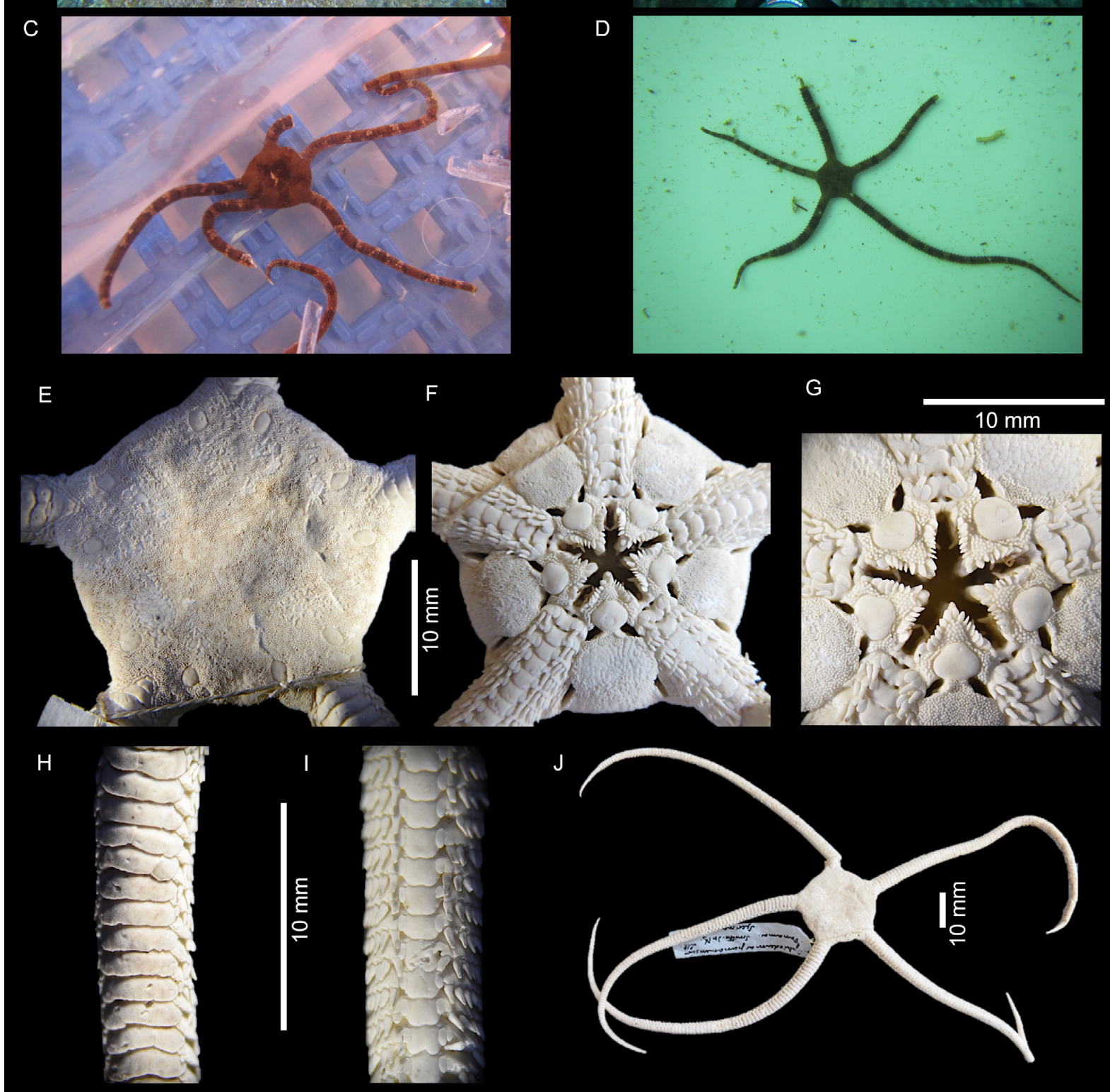

Fig. 5. A-D. Ophioderma hendleri sp. nov. A-B. In vivo coloration in natural habitat. C-D. In vivo coloration of collected specimens. - E-J. Ophioderma panamense Lütken, 1859, holotype (NHMD107679, DD $=21.9$ mm). E. Dorsal disc. F. Ventral disc. G. Mouth. H. Dorsal arm. I. Ventral arm. J. Dorsal view. 
Table 1. Comparison of morphological characters between some species of Ophioderma from the Eastern Pacific.

\begin{tabular}{|c|c|c|c|c|}
\hline & O. hendleri sp. nov. & O. panamense & O. pentacanthum & O. variegatum \\
\hline Radial shields & covered by granules & naked & covered by granules & covered by granules \\
\hline Base of the arms & $\begin{array}{c}\text { covered by granules } \\
\text { and scales }\end{array}$ & $\begin{array}{l}\text { covered by granules } \\
\text { and scales }\end{array}$ & $\begin{array}{l}\text { covered by granules } \\
\text { and scales }\end{array}$ & covered by granules \\
\hline Arm-spines & $\begin{array}{l}\text { up to } 11 \text {; short and } \\
\text { more or less robust }\end{array}$ & $\begin{array}{c}\text { up to } 12 \text {; short and } \\
\text { robust }\end{array}$ & $\begin{array}{l}\text { up to } 6 \text {; large and thin, } \\
\text { the ventral-most being } \\
\text { much larger and robust }\end{array}$ & $\begin{array}{c}\text { up to } 9 \text {; very large and } \\
\text { thin }\end{array}$ \\
\hline Tentacle scales & $\begin{array}{c}\text { adradial slightly larger } \\
\text { than abradial }\end{array}$ & $\begin{array}{l}\text { adradial slightly larger } \\
\text { than abradial }\end{array}$ & $\begin{array}{l}\text { adradial much larger } \\
\text { than abradial }\end{array}$ & $\begin{array}{c}\text { adradial slightly larger } \\
\text { than abradial }\end{array}$ \\
\hline Oral shields & $\begin{array}{l}\text { broader than long, } \\
\text { rounded triangular, } \\
\text { with rounded obtuse } \\
\text { proximal angle, } \\
\text { straight distal edge, } \\
\text { obtuse lateral angles }\end{array}$ & $\begin{array}{l}\text { broader than long, } \\
\text { rounded triangular, } \\
\text { with rounded obtuse } \\
\text { proximal angle, } \\
\text { straight distal edge, } \\
\text { obtuse lateral angles }\end{array}$ & $\begin{array}{l}\text { broader than long, } \\
\text { rounded triangular, } \\
\text { with rounded obtuse } \\
\text { proximal angle, } \\
\text { straight distal edge, } \\
\text { obtuse lateral angles }\end{array}$ & $\begin{array}{l}\text { longer than broad, } \\
\text { oval, proximal margin } \\
\text { rounded obtuse angled, } \\
\text { distal edge convex, } \\
\text { lateral margins straight }\end{array}$ \\
\hline Adoral shields & $\begin{array}{c}\text { naked; equally long as } \\
\text { broad }\end{array}$ & covered by granules & $\begin{array}{l}\text { naked; longer than } \\
\text { broad }\end{array}$ & $\begin{array}{l}\text { naked; longer than } \\
\text { broad }\end{array}$ \\
\hline Genital slits & $\begin{array}{l}\text { short and rounded; } \\
\text { distally surrounded by } \\
\text { granules and scales }\end{array}$ & $\begin{array}{l}\text { short and rounded; } \\
\text { distally surrounded by } \\
\text { granules and scales }\end{array}$ & $\begin{array}{l}\text { large and slender; } \\
\text { distally surrounded by } \\
\text { granules and scales }\end{array}$ & $\begin{array}{l}\text { short and rounded; } \\
\text { distally surrounded } \\
\text { only by scales }\end{array}$ \\
\hline Coloration in vivo & $\begin{array}{l}\text { disc dark brown } \\
\text { mottled with small and } \\
\text { white spots, ventral } \\
\text { margin beige; arms } \\
\text { with transverse white } \\
\text { bands }\end{array}$ & $\begin{array}{l}\text { disc green, brown } \\
\text { or grey mottled with } \\
\text { red, orange or yellow, } \\
\text { sometimes a central } \\
\text { white spot; arms with } \\
\text { transverse bands } \\
\text { lighter and darker }\end{array}$ & $\begin{array}{c}\text { disc orange with dark } \\
\text { brown blotches; arms } \\
\text { with transverse brown } \\
\text { bands }\end{array}$ & $\begin{array}{l}\text { disc olive-green with } \\
\text { dark pink or red; arms } \\
\text { with transverse olive- } \\
\text { green and dark pink- } \\
\text { red bands }\end{array}$ \\
\hline Depth & intertidal $-37 \mathrm{~m}$ & intertidal $-20 \mathrm{~m}$ & $102-183 \mathrm{~m}$ & intertidal - $110 \mathrm{~m}$ \\
\hline
\end{tabular}

Dorsal base of arms covered by granules and with approximately 11 oval scales, located laterally at first 3 dorsal arm plates (Fig. 1E). Dorsal arm plates $3 \times$ broader than long, rectangular, overlapping; proximal edge straight, distal edge slightly concave with rounded lateral edges (Fig. 1F). Distalmost dorsal arm plates smaller, longer than broad, triangular. First ventral arm plate small, broader than long, with rounded edges; in contact with adoral shields. Second ventral arm plate quadrangular, as broad as long (Fig. 1C). Next ventral arm plates slightly longer than broad, quadrangular; proximal margin truncate and distal edge convex (Fig. 1G). Distalmost ventral arm plates wider distally, with a tapering proximal angle. Paired rounded depressions between most proximal ventral arm plates (Fig. 1B). LAPs conspicuous, semicircular, broader than long (Fig. 1H). LAP with up to $11 \mathrm{arm}$ spines. First and $2^{\text {nd }}$ LAP with 3 arm spines; $3^{\text {rd }}$ with 4 arm spines; $4^{\text {th }}$ with $5 ; 5^{\text {th }}$ with $6 ; 6^{\text {th }}$ with $7 ; 7^{\text {th }}$ with $8 ; 8^{\text {th }}$ with 9 ; $9^{\text {th }}-30^{\text {th }}$ arm plates with $10-11$ arm spines; $35^{\text {th }}$ with 9 spines; $40^{\text {th }}-50^{\text {th }}$ with $8 ; 60^{\text {th }}$ with $7 ; 70^{\text {th }}$ with 6 ; $75^{\text {th }}$ with $5 ; 80^{\text {th }}$ with $4 ;>80^{\text {th }}$ with 3 arm spines. Arm spines with blunt tip; length approximately $1 / 3$ of LAP. Dorsalmost arm spine shortest, blunt; ventralmost arm spine longest and more robust, as long as $1 \mathrm{arm}$ segment, almost in contact with tentacle scale of succeeding joint (Fig. 1H). Two tentacle scales; adradial tentacle scale ovoid, approximately $1 / 2 \times$ length of ventral arm plate; abradial tentacle scale slightly shorter, subtriangular (Fig. 1G).

General coloration dark brown (dry specimen) (Fig. 1I). Dorsal side: disc dark brown and mottled with small white spots; middle of margin on each interradius of disc bearing white spot (Fig. 1A); arms 
dark brown with small black spots only observed microscopically and with every 5-6 arm plates with transverse white bands, located between distal part of ventral plate and proximal part of next arm plate (Fig. 1F, I). Ventral side: interradii, center and proximal part beige, margin dark brown with some beige marks (Fig. 1B). Jaw beige but oral shields can display brown color (Fig. 1C). Ventral arm plates beige, but that on tip of arms dark brown with some beige transversal lines (Fig. 1G). LAPs dark brown with some beige marks; arm spines dark brown and generally beige color on base and tip (Fig. 1H).

\section{Disarticulated ossicles}

Specimen analyzed: 1 spec., paratype ICML-UNAM 18323 (DD $=15 \mathrm{~mm}, \mathrm{AL}=80.8 \mathrm{~mm}$ ). Radial shield (external view) irregularly triangular, with convex proximal margin, incised abradial edge with projection, convex to straight distal edge and irregular adradial edge, series of 8 pores on median to proximal margin (which are covered/overlapped by disc scales and granules in intact animal) (Fig. 2AB), most proximal ones deepest. Center of distal portion of radial shield covered in intact animal. Outer surface of stereom is open mesh of pores and small knobs (Fig. 2C). Dorsal arm plate slightly arched and somewhat rectangular, $3 \times$ as wide as long; proximal margin convex and distal margin straight, 1 spur on proximal portion of external surface (Fig. 2D). Ventral arm plate as long as wide, quadrangular with proximal side truncated and pointed spur, lateral sides concave forming border of tentacle pore (Fig. 2E). LAP D-shaped, $2 \times$ as high as wide, with 8 spine articulations sunken in notches of distal edge (Fig. 2F-G). Ventral portion of LAP projecting ventro-proximalwards and ventro-distal tip projecting ventralwards (Fig 2F). Ventro-proximal margin with condyle (Fig. 2F). Proximal edge of LAP with 2 prominent and elongated spurs, protruding and modifying central-proximal edge (Fig. 2F), between spurs and across remaining proximal margin discernible band of different stereom structure (Fig. 2F). Outer surface finely meshed with relatively large polygonal knobs (Fig. 2I). Inner surface of LAP with continuous ridge on proximal edge, and at ventro-distal margin 2 spurs matching those on external surface (Fig. 2H), and 3 pores just below center. Spine articulations ventralwards increasing in size (Fig. $2 \mathrm{G})$. Lobes with weak sigmoidal fold, tilted, curved, slightly joined on proximal margin by 3 or 4 knobs; ventral lobe smaller than dorsal lobe (Fig. 2J). Proximal vertebrae almost round, as wide as long, with large aboral muscle flange and smaller oral muscle flange (Fig. 2L). Distal face of vertebrae with large muscle flanges, with typical zygospondylous articulation (Fig. 2K). Tentacle scale longer than wide, with scale-like surface (Fig. 2M). Spines with scale-like surface and blunt tip (Fig. 2N). Dental plate consists of several pieces, $1^{\text {st }}$ piece bears 2 TPas on small round socket and 1 wide tooth socket, while rest of pieces with single tooth socket per piece (4 in total), none of sockets penetrate plate (Fig. 2O). Oral plates as long as high, abradial face with muscle fossa highly triangular, almost covering whole surface (Fig. 2P), adradial face in middle part with foot basin (Fig. 2Q).

\section{Paratype variations}

Large specimens showed some differences in morphology compared to small ones (Figs 1, 3-4). Large individuals have granules and scales on the base of the arms (Fig. 1E), but in the smallest specimens $(\mathrm{DD}=\sim 2-4 \mathrm{~mm}$ ) the scales are covered by granules (Fig. 4B). The scales begin to appear as the animal grows; therefore, in specimens with $\mathrm{DD}=4-6 \mathrm{~mm}$ there are up to 3 elongated scales to either side of the base of the arms (Fig. 3B), and with a DD $=7 \mathrm{~mm}$ there are up to six scales; the number of scales in larger specimens reaches 11 (Fig. 1E). Additionally, large individuals have numerous scales located on the distalmost part of the interradii (Fig. 1B) but in the smallest specimens (DD $=3-6 \mathrm{~mm}$ ) these scales are not evident, and instead, only granules are present (Figs $3 \mathrm{~F}-\mathrm{G}, 4 \mathrm{~F}-\mathrm{G}$ ). In specimens larger than $\mathrm{DD}=7 \mathrm{~mm}$, a row of elongated scales in the distal genital slits is evident. Finally, in the smallest specimens the adoral shields are completely covered by granules, which disappear as the animal grows, and individuals with $\mathrm{DD}=5 \mathrm{~mm}$ tend to have totally or partially covered adoral shields. 
Some specimens can have beige specks on the LAPs, the arm spines and the tentacle scales. Moreover, some specimens from the Gulf of California (Mexico) have a large white spot in the center of the dorsal disc. It is important to note that in vivo coloration (Fig. 5A-D), generally conserved in all preserved specimens (Figs 1, 3-4), can be used as a distinctive character in the field.

\section{Habitat and distribution}

Widely distributed in the Eastern Tropical Pacific. Ophioderma hendleri sp. nov. has been collected in the Mexican Pacific from the Gulf of California (in the States of Sonora and Baja California Sur), Jalisco, Michoacán, Guerrero and Oaxaca as well as in Revillagigedo, Marías and Marietas Islands. In Costa Rica it has been collected from Murciélago, Caño, and Cocos Islands; in Panama from Pearl Islands; and finally, in Colombia from the localities La Parguera and La Roñosa Rock (see: Supplementary material). The northernmost locality of its distribution is off San Francisquito Bay (Gulf of California, Mexico; $\left.28^{\circ} \mathrm{N}\right)$ and the southernmost point is La Roñosa Rock, Colombia $\left(3^{\circ} \mathrm{N}\right)$. Due to its distribution, $O$. hendleri sp. nov. can be considered as a species with a Panamic affinity, suggesting that, similar to other ophiuroids (e.g., Ophiocoma aethiops Lütken, 1859 and Ophiocomella alexandri (Lyman, 1860)), its distribution may extend to northern Peru, where a transitional zone between the Panamic and the Peruvian Provinces is located (Granja-Fernández \& Hooker 2020), but more sampling effort is needed to confirm its presence or absence in this area. The species inhabits depths between 0.40 $37 \mathrm{~m}$. Ophioderma hendleri sp. nov. is mostly collected under rocks, burrowed in the sediment and it is common to find it associated with coral and rocky reefs (Granja-Fernández et al. 2014).

\section{Remarks}

Ophioderma hendleri sp. nov. is one the most widely distributed ophiodermatids in the Eastern Tropical Pacific and it is of interest to note that although it has been collected since 1936, it has been misidentified in all the reviewed collections as O. variegatum or O. panamense (see Discussion). In previous works, Granja-Fernández et al. $(2014,2015 \mathrm{a}, 2017)$ mentioned the presence of Ophioderma sp. 1, which actually corresponds to $O$. hendleri sp. nov.; therefore, these records are considered to be this species.

In our revision of the specimens, we did not observe any differences in the morphological characters from different geographical areas, suggesting that intraspecific variation in $O$. hendleri sp. nov. is not related to its distribution. On the other hand, it is very notable that this species in most cases presents the same color pattern (dorsal side dark brown, ventral side beige and arms with transversal lines; Figs 1, 3-5), with some exceptions (see Paratype variations). This is in contrast to other Ophioderma species such as $O$. panamense or $O$. variegatum, which can display a great variety of colors (green, yellow, pink, etc.; Nielsen 1932; Ziesenhenne 1955).

This species is commonly found at the same localities as $O$. panamense and other ophiuroids such as Ophiactis simplex (Le Conte, 1851), Ophiactis savignyi (Müller \& Troshel, 1842), Ophiocoma aethiops, Ophiocomella alexandri, Ophionereis annulata (Le Conte, 1851), Ophiothela mirabilis Verrill, 1867 and Ophiothrix (Ophiothrix) spiculata Le Conte, 1851. It is one of the most conspicuous Ophioderma species of the Eastern Tropical Pacific and it is always hiding under small and medium-sized rocks and in sediment of median size of rocky and coral reefs (Fig. 5A-B). Its abundance has not been quantified, but using scuba diving, in an hour of sampling effort of all the species of ophiuroids at one locality, a total of 5-6 specimens were found, a smaller number compared to $O$. panamense ( $8-12$ specimens). It tends to be gregarious, and it is very common to find at least two specimens occupying the same space. Field notes denote that $O$. hendleri sp. nov. has been found in waters with a bottom temperature of $27-29^{\circ} \mathrm{C}$. 
Ophioderma panamense Lütken, 1859

Figs 5E-J, 6; Table 1

Ophioderma panamensis Lütken, 1859: 193.

Ophiocryptus granulosus Nielsen, 1932: 334-335, fig. 38.

Ophiura panamensis - Lyman 1865: 32-34. - Verrill 1867: 253-254. — Ives 1889b: 175.

Ophioderma panamensis - Ives 1889a: 76-77. — Koehler 1907: 282. — McClendon 1909: 35, fig. 1. — H.L. Clark 1913: 205; 1915: 300-301. - Campbell 1921: 2, fig. 1. — Caso 1951: 265-272, figs 25-28; 1962: 296, 302; 1979: 210, pl. 97-100; 1986: 225, 239, pl. 14-19. — Granja-Fernández et al. 2014: 132-134, fig. 6a-f; 2015a: 41; 2015b: 95; 2017: 172, 174.

Ophioderma panamense - H.L. Clark 1915: 301-302; 1917: 443; 1940: 341-342. - Nielsen 1932: 327-330. - Ziesenhenne 1937: 227, 1955: 192-197. — Boolotian \& Leighton 1966: 10, fig. 23. — Luke 1982: 33. — Solís-Marín et al. 2005: 128; 2013: 570. — Honey-Escandón et al. 2008: 63. - Alvarado et al. 2010: 48.

Ophiocryptus granulosus - Honey-Escandón et al.2008: 63. — Cortés 2012: 173. — Granja-Fernández \& López-Pérez 2012: 363. — Bastida-Zavala et al. 2013: 367. — Solís-Marín et al. 2013: 569.

\section{Diagnosis}

Radial shields naked, oval, small, and widely separated. Adoral shields covered by granules. Up to 12 arm spines, short and with a blunt tip. In vivo coloration: disc green, brown or grey mottled with red, orange or yellow; arms with transverse bands, lighter and darker.

\section{Material examined}

Holotype

PANAMA • 1 spec.; Panama; NHMD-107679.

\section{Other material}

See: Supplementary material.

\section{Holotype redescription}

$\mathrm{DD}=21.9 \mathrm{~mm} ; 5 \mathrm{arms}, \mathrm{AL}=91.9 \mathrm{~mm}$. Disc flat and pentagonal. Dorsal disc densely covered by rounded and small granules, granule density $61 \mathrm{~mm}^{-2}$; rubbed off in some areas. Radial shields naked, small, oval, and separated (Fig. 5E). Ventral interradii covered with granules similar to those on dorsal side of disc (Fig. 5F). Four genital slits on each interradius; proximal genital slits rounded and shorter than distal slits, in contact with distal part of oral shield and with $1^{\text {st }}$ LAP; distal genital slits elongated and surrounded by granules and numerous and imbricated scales next to lateral arm plates (Fig. 5F).

Oral shields slightly broader than long, rounded triangular, with convex obtuse proximal angle, straight distal edge, obtuse lateral angles. Madreporite with a small, circular, and shallow depression located in distal part and larger than other oral shields. Adoral shields covered by granules, which are larger than those on rest of body. Jaws bear 7-8 papillae at each side: LyOs small, $1.5 \times$ as long as broad, angled upwards; AdShSp largest, rounded; $2^{\circ} \mathrm{AdShSp}$ a little larger and similar in shape to LOPa; LOPa 3-4 conical and pointed, separated; IPa similar and separated from LOPa; TPa 1-2 at jaw tips, robust and pointed, larger and more robust than LOPa, widely separated. vT similar in shape but slightly larger than TPa. OPRSp 1, large and pointed at each side, visible within buccal cavity. Granules covering oral plates, larger than those on dorsal disc and interradii (Fig. 5G).

Dorsal base of arms covered by granules and with approximately 15 scales laterally at dorsal arm plates. Dorsal arm plates $3 \times$ broader than long, overlapping and with an irregular to straight proximal 

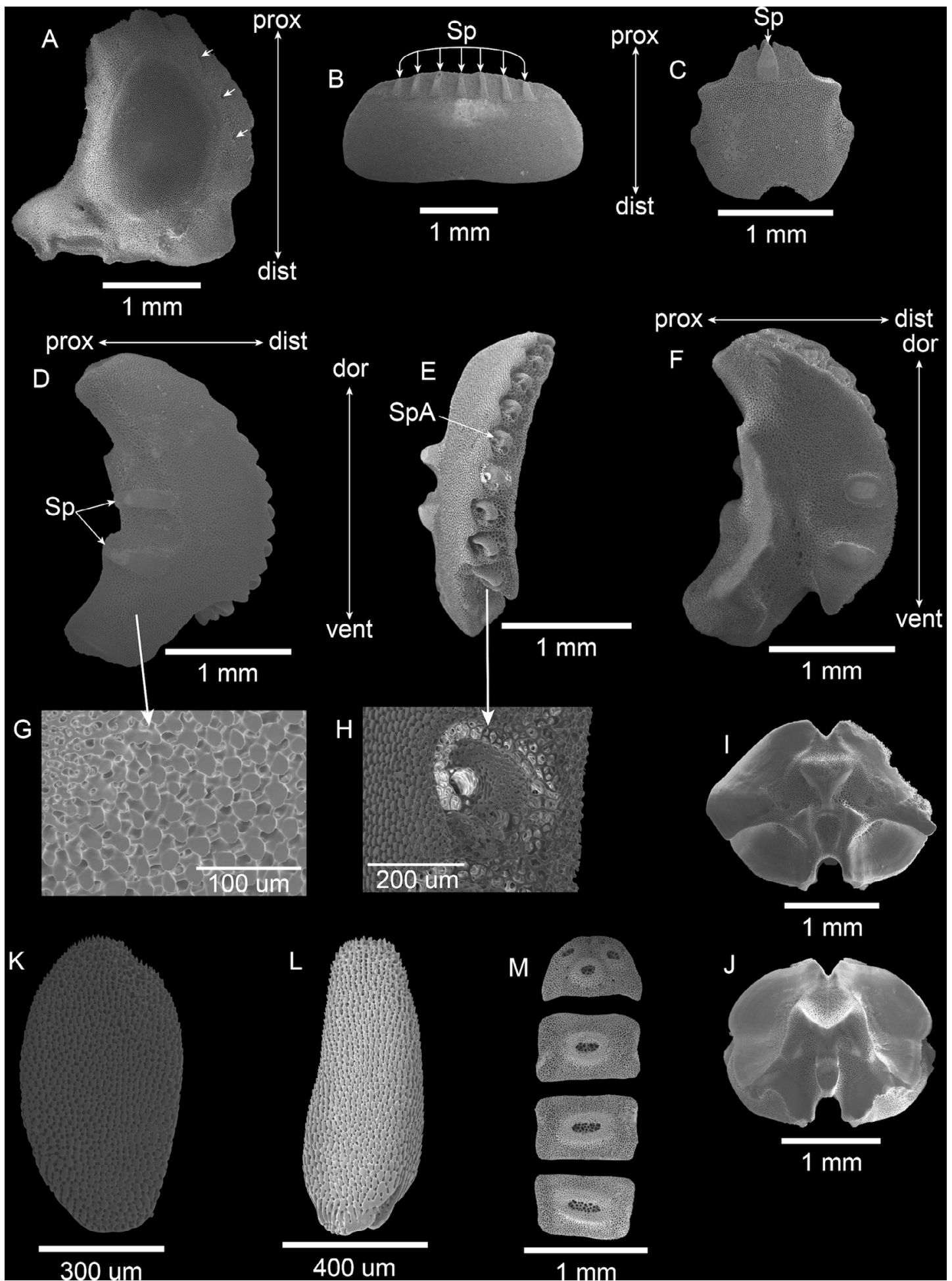

Fig. 6. SEM images of skeletal elements of Ophioderma panamense (ICML-UNAM 3.18.60, DD = $11.1 \mathrm{~mm}$ ). A. Radial shield (external view), the pores marked with arrows. B. Dorsal arm plate, with seven spurs. C. Ventral arm plate with one spur. D. Lateral arm plate, external face, with two spurs. E. Lateral arm plate, lateral face, with spine articulations. F. Lateral arm plate, internal face. G. Outer surface of the LAP(D) with fine mesh and rounded knobs. H. Spine articulations with a weak sigmoidal fold and tilted lobes. I. Arm vertebra, proximal face. J. Arm vertebra, distal face. K. Tentacle scale. L. Arm spine. M. Dental plate fragments. 
and distal margin, with rounded lateral edges; a few dorsal arm plates can be fragmented in 2 pieces (Fig. 5H). First ventral arm plate small, broader than long; with a small indentation distally (Fig. 5G). Subsequent ventral arm plates quadrangular, slightly broader than long; distal edge slightly concave (Fig. 5I). Paired and rounded pores between $1^{\text {st }}$ and $2^{\text {nd }}$, and $2^{\text {nd }}$ and $3^{\text {rd }}$ ventral arm plates (Fig. 5F-G). LAP with up to 8-9 arm spines. Arm spines with blunt tip and robust; length approximately $1 / 2$ of size of LAP. Dorsalmost arm spine shortest and narrowest; ventralmost arm spine longest and slightly more robust, in contact with tentacle scale of succeeding joint (Fig. 5I). Two tentacle scales; adradial tentacle scale ovoid, elongated, approximately half length of ventral arm plate; abradial tentacle scale slightly shorter, subtriangular (Fig. 5I).

Color pattern beige in ethanol, likely faded (Fig. 5J).

\section{Disarticulated ossicles}

Specimen analyzed: 1 spec., ICML-UNAM 3.18.60 (DD = $11.1 \mathrm{~mm}, \mathrm{AL}=44.4 \mathrm{~mm})$. Radial shield (external view) irregularly rounded, with an indented proximal margin, an incised abradial edge with a projection, an indented distal edge, and convex adradial margin, it is bordered by 7 pores on median to proximal margin (which are covered/overlapped by disc scales and granules in intact animal) (Fig. 6A). Only exposed surface is domed center portion of radial shield. Outer surface of stereom is an open mesh of pores and knobs (Fig. 6A). Dorsal arm plate somewhat rectangular, $3 \times$ as wide as long; proximal margin convex to straight, and distal margin straight, 7 spurs on proximal portion of external surface (Fig. 6B). Ventral arm plate as long as wide, quadrangular with proximal side truncated and with a pointed-shape spur, lateral sides concave forming border of a small tentacle pore, and distally indented (Fig. 6C). LAP D-shaped, $3 \times$ as high as wide, with 8 spine articulations sunken in notches of distal edge (Fig. 6D-E). Ventral portion of LAP projecting ventro-proximalwards and ventro-distal tip projecting ventralwards (Fig. 6D). Proximal edge of LAP with 2 prominent and elongated spurs, which are protruding and modify central-proximal edge (Fig. 6D); between spurs and across remaining proximal margin a discernible band of different stereom structure is present (Fig. 6D). Outer surface finely meshed with relatively large rounded stereom knobs (Fig. 6G). Inner surface of LAP with a continuous ridge on proximal edge, and on ventro-distal margin with 2 spurs matching those on external surface (Fig. 6F), and 4 pores in center. Spine articulations ventralwards increasing in size (Fig. 6E). Lobes with a weak sigmoidal fold, tilted, and curved (Fig. 6H). Ventral lobe smaller than dorsal lobe (Fig. 6H). Proximal vertebrae (Fig. 6I) almost oval, as wide as long, with large aboral muscle flange and smaller oral muscle flange. Distal face of vertebrae with large muscle flanges, with typical zygospondylous articulation (Fig. 6J). Tentacle scale longer than wide, with a scale-like surface (Fig. 6K). Spines with a scale-like surface, a blunt tip, and laterally flattened (Fig. 6L). Dental plate consists of several pieces, $1^{\text {st }}$ piece bears $2 \mathrm{TPa}$ and a single wide tooth, while rest of pieces with a single tooth socket per piece (4 in total), none of sockets penetrate plate (Fig. 6M).

\section{Habitat and distribution}

USA (California), Mexico (Baja California, Gulf of California, Nayarit, Jalisco, Colima, Michoacán, Guerrero, Oaxaca, Marías Islands, Marietas Islands, Revillagigedo Islands), El Salvador, Nicaragua, Costa Rica (Caño Island, Cocos Island, Murciélagos Islands), Panama, Colombia, Ecuador (Galapagos Islands), and Peru (Solís-Marín et al. 2013; Granja-Fernández et al. 2014). From intertidal to $20 \mathrm{~m}$ depth (Solís-Marín et al. 2013). Found under rocks and in rubble, coral, sand, algae, and tide pools (Maluf 1988; Granja-Fernández et al. 2014).

\section{Remarks}

Lütken (1859) did not designate any specific type material in his description of $O$. panamense, but according to the International Code of Zoological Nomenclature (ICZN 1999), Article 73.1.2, the only specimen reported in the original description (NHMD-107679) must be treated as holotype by monotypy. 
The description provided by Lütken (1859) is mostly based on the comparison of this species with other Ophioderma from the Atlantic; therefore, a redescription of the holotype is provided in the present work.

We observed that the holotype, as well as adult voucher specimens, can have some 'fragmented' or 'broken' dorsal arm plates (Fig. 5H) indicating that they might have been crushed by moving between rocks and these disruptions are the result of injury (Ziesenhenne 1955; Stöhr et al. 2020b). Hendler (2018) observed that 'fragmented' dorsal arm plates in $O$. panamense frequently occur on basal arm segments of adult specimens, but are rare on distal arm segments of adults and juveniles. It is important to emphasize that these fragmentations on the dorsal arm plates are a result of mechanical damage and are not an inherent feature of the species as occurs in O. peruanum, O. teres or O. vansyoci.

Along with $O$. hendleri sp. nov., $O$. panamense is one of the most conspicuous and abundant ophiuroids in the Eastern Pacific, but it has often been confused with $O$. teres and $O$. variegatum (see Discussion section). Due to its commonness, $O$. panamense is one of the most studied and commented species of the Eastern Pacific (Lyman 1865; Verrill 1867; Ives 1889a; McClendon 1909; Nielsen 1932; Ziesenhenne 1955; Granja-Fernández et al.2014), but many of these studies may be based on misidentified specimens.

Ophioderma pentacanthum H.L. Clark, 1917

Fig. 7, Table 1

Ophioderma pentacantha H.L. Clark, 1917: 443-444, pl. 3-4, figs 1-2.

Ophioderma pentacanthum - Ziesenhenne 1955: 197. — Downey 1969: 115. — Maluf 1988: 83, 203. — Buitrón-Sánchez \& Solís-Marín 1993: 221.

Ophioderma pentacantha - Maluf 1991: 354. - Hickman 1998: 25. - Pineda-Enríquez et al. 2013: 60-62. — Solís-Marín et al. 2013: 570. — Tirado-Sánchez et al. 2014: 24. — Granja-Fernández et al. 2015a: 41.

\section{Diagnosis}

Radial shields covered by very small granules. Naked adoral shields, longer than broad. First ventral arm plate large and rhombic. Up to 6 arm spines, very large and slender; the dorsalmost is the shortest and the ventralmost is much larger than the rest, overlapping the tentacle scales of the contiguous segment. Adradial tentacle scale almost double in size of abradial one. In vivo coloration: disc orange with dark blotches, arms with transverse brown bands.

\section{Examined material}

Holotype

ECUADOR - 1 spec.; Galapagos, Hood Island, 5 miles SW of Ripple Point, Albatross Station 4643; $1^{\circ} 29^{\prime} 0^{\prime \prime} \mathrm{S}, 8^{\circ} 48^{\prime} 30^{\prime \prime} \mathrm{W}$; 183 m (100 fms); 7 Nov. 1904; Albatross Expedition leg.; broken shells and globigerina; USNM E726.

\section{Paratypes}

ECUADOR • 1 spec.; same collection data as for holotype; MCZ OPH-4519 1 spec.; same collection data as for holotype; USNM E9798.

\section{Other material}

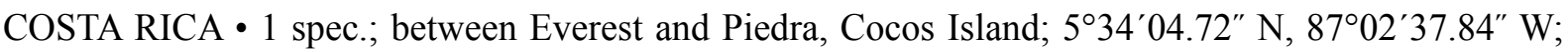
102 m; 15 Oct. 2016; DeepSee submersible (Dive 2377) leg.; MZUCR-ECH 1413 • 1 spec.; Parque Nacional Isla del Coco; 5³4'35.21" N, 8703'27.96" W; 142 m; 14 Sep. 2013; DeepSee submersible leg.; MZUCR-ECH 1414 • See: Supplementary material. 


\section{Description (paratype MCZ OPH-4519)}

$\mathrm{DD}=21.1 \mathrm{~mm} ; 5 \mathrm{arms}, \mathrm{LA}=147.7 \mathrm{~mm}$. Disc flat and rounded. Dorsal disc densely covered by rounded and fine granules, which are very close together, granule density $182 \mathrm{~mm}^{-2}$; granules extend to base of arms. Some granules rubbed off in some areas of disc. Radial shields completely covered by granules (Fig. 7A). Interradii covered with granulation, similar to on dorsal disc (Fig. 7B). Four genital slits on each interradius; proximal and distal genital slits elongated; distal genital slits surrounded by granules and few scales that are next to side of lateral arm plates (Fig. 7B).

Oral shields broader than long, rounded triangular, with convex obtuse proximal angle, straight distal edge, obtuse lateral angles. Madreporite with a small, circular, and shallow depression located in distal part of oral shield. Adoral shields naked, triangular, longer than broad, and separated. Jaws bear 8-9 papillae on each side: LyOs small, $1.5 \times$ as long as broad, angled upwards; AdShSp largest, rounded; $2^{\circ} \mathrm{AdShSp}$ smaller but similar in shape to AdShSp; LOPa 3-4 conical, pointed, and separated, $1^{\text {st }} \mathrm{LOPa}$ smaller but similar in shape to $2^{\circ} \mathrm{AdShSp}$; IPa sometimes smallest, elongated, pointed and separated; TPa 2 at jaw tips, larger than LOPa, elongated, robust, and pointed, slightly or completely separated. vT 1; 4 teeth, all robust. OPRSp 1 large and pointed at each side, visible within buccal cavity. Granules covering oral plates, slightly longer than those on dorsal disc and interradii (Fig. 7C).

Dorsal base of arms with granules and with approximately 11 scales laterally at arm. Dorsal arm plates $3 \times$ broader than long, overlapping and trapezoidal, with distal edge straight or slightly incised and rounded lateral edges (Fig. 7D). First ventral arm plate large, broader than long, rhomboid (Fig. 7C). Subsequent ventral arm plates quadrangular, slightly broader than long (Fig. 7E). Paired and large pores between ventral arm plates $1-2,2-3,3-4,4-5,5-6$ (Fig. 7B, G). LAP with up to 5-6 arm spines; distalmost segments with 3-4 arm spines. Arm spines with a blunt tip, slender and very large; approximately one arm segment length. Dorsalmost arm spine shortest and slender; ventralmost arm spine longest and more robust than rest, in contact with and covering tentacle scale of succeeding joint (Fig. 7E). Two tentacle scales; adradial tentacle scale ovoid and very elongated; abradial tentacle scale subtriangular and half size of adradial one (Fig. 7E, G).

Color light brown (dry specimen) (Fig. 7F). Dorsal side: disc light brown and mottled dark brown in center (Fig. 7A); arms light brown with transverse dark brown bands every 2 or 3 segments (Fig. 7D, F). Ventral side interradii: beige in center and in proximal part, and light brown on margin, with some beige marks (Fig. 7B). Jaw in general beige, but oral shields and granules brown in color (Fig. 7C). Ventral arm plates beige (Fig. 7E).

\section{Habitat and distribution}

Previously known only for Galapagos Islands, Ecuador (H.L. Clark 1917; Ziesenhenne 1955; Downey 1969; Maluf 1988; Hickman 1998; Solís-Marín et al. 2013). In this work, a new distribution record is reported for Cocos Island, Costa Rica (MZUCR-ECH 1413, MZUCR-ECH 1414; see Remarks). From 102-183 m depth (H.L. Clark 1917). Collected in broken shells (H.L. Clark 1917).

\section{Remarks}

In the original description of $O$. pentacanthum, H.L. Clark (1917) designated an uncatalogued specimen as "heliotype" (= holotype), including four additional specimens, but a proper designation of the type material (including catalog numbers) was lacking at that moment. Downey (1969) considered the specimen USNM E726 $(D D=27 \mathrm{~mm})$ as paratype, not recognizing it as the holotype in spite of a museum label marking it as type material by H.L. Clark (pers. comm. Pawson, 2020), also not considering the illustration already included in the original description. However, according to the International Code of Zoological Nomenclature (ICZN 1999), Articles 73.1.2 and 73.1.4, the described and illustrated 


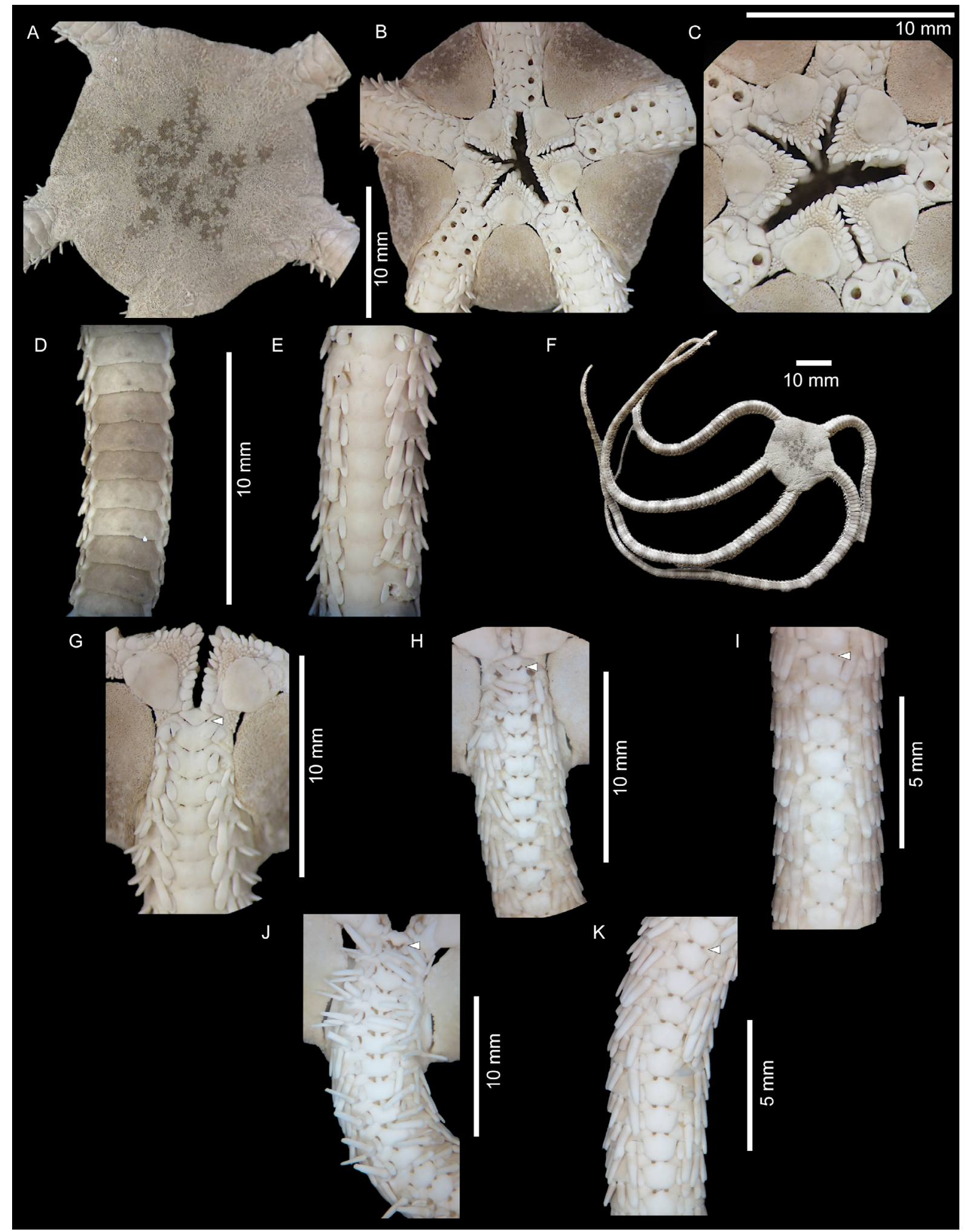

Fig. 7. Ophioderma pentacanthum H.L. Clark, 1917, paratype (A-G $=$ MCZ OPH-4519, DD $=21.1 \mathrm{~mm}$ $\mathrm{H}-\mathrm{I}=$ MZUCR-ECH 1413, DD = $23.0 \mathrm{~mm}$; J-K = MZUCR-ECH 1414, DD = $26.8 \mathrm{~mm}$ ). A. Dorsal disc. B. Ventral disc. C. Mouth. D. Dorsal arm. E. Ventral arm. F. Dorsal view. G. Pores between proximal ventral arm plates. H. Pores in proximal ventral arm plates. I. Pores in median ventral arm plates. J. Pores in proximal ventral arm plates. K. Pores in median ventral arm plates. 
specimen which corresponds to USNM E726 should be treated as the holotype. During the revision of the paratypes only two specimens were found: MCZ OPH-4519 and USNM E9798. The labels of the paratype USNM E9798 indicate the presence of two specimens, but the lot includes only one. Therefore, two specimens are "lost", one that is part of USNM E9798, and a second one whose catalog number is unknown, but in case they are found, they must be treated as paratypes.

All the morphological characters of the holotype, paratypes, and voucher specimens correspond with the original description by H.L. Clark (1917); nevertheless, we observed other relevant characters. H.L. Clark (1917) coined the named $O$. pentacanthum based on the number of arm spines (five), but we observed that most of the examined specimens (MCZ OPH-4519, MZUCR-ECH 1413, MZUCR-ECH 1414) had up to six arm spines. It is important to mention that the low number of arm spines is one of the most important diagnostic characters for this species since $O$. pentacanthum is the only Ophioderma in the Eastern Pacific having up to six arm spines, while the rest of its congeners have more than eight. Another important characteristic that has not previously been mentioned is the elongation of the genital slits (Fig. 7G-H, J), which is not found in other Ophioderma from the Eastern Pacific; perhaps, the large elongation of these genital slits is due to the large size of the specimens, but this must be confirmed when more data from specimens of different sizes is obtained. One of the most remarkable features of $O$. pentacanthum is the paired and large pores between the most proximal ventral arm plates. The paratype MCZ OPH-4519 (Fig. 7G) presents them on at least the first six arm segments, but they cover $3 / 4$ of the arm in the Costa Rican specimens (Fig. $7 \mathrm{H}-\mathrm{K}$ ). Furthermore, the observed pores in such specimens are extremely large (occupying most of the proximal portion of the ventral arm plates) and elongated in the first segments (Fig. 7H, J), decreasing in size and becoming more rounded towards the medial (Fig. 7I, K) and distalmost part of the arm. The reason why H.L. Clark (1917) did not observe these pores could be related to the smaller size of the type material (MCZ OPH-4519, DD $=21.1 \mathrm{~mm}$ ) in comparison to the specimens from Costa Rica (MZUCR-ECH 1413, DD = $23 \mathrm{~mm}$; MZUCR-ECH $1414, \mathrm{DD}=26.8 \mathrm{~mm}$ ). Taking into account all the nominal species, it seems that smaller specimens of Ophioderma tend to have reduced and fewer pores (or even absent) in the ventral part of the arm, whilst larger specimens can have larger and more numerous pores being a characteristic inherent of growth; this agrees with observations made by Nielsen (1932). Nevertheless, more specimens are necessary to review and compare to corroborate this assumption and to determine whether the pores have any functional importance in the organisms (pers. com. Stöhr \& Granja-Fernández, 2017). Lastly, it is important to remark that the field notes of the specimens from Costa Rica mentioned that the in vivo color of O. pentacanthum was orange with brown botches on the disc and arms with transversal brown bands; this is the first record of the in vivo coloration for this species.

H.L. Clark (1917) described this species from the Galapagos Islands but it was subsequently recorded in the Gulf of California, Mexico, and Guatemala (Ziesenhenne 1955; Solís-Marín et al. 2013). In the review of the genus Ophioderma by Ziesenhenne (1955), he mentioned that the occurrence of O. pentacanthum in the Gulf of California (one specimen deposited in the Allan Hancock Collection) was "rare". Nevertheless, many authors have considered this record as valid (Maluf 1991; Buitrón-Sánchez \& Solís-Marín 1993; Maluf \& Brusca 2005; Granja-Fernández et al. 2015a). We reviewed all the LACM Ophioderma material, where all the material of the Allan Hancock Foundation is deposited, and we could not find any material corresponding to Ziesenhenne's record. Moreover, in all the other visited collections we did not find any specimens labeled and/or identified as $O$. pentacanthum, except for the type material from the Galapagos Islands. Despite the rarity of $O$. pentacanthum in scientific collections, the reviewed specimens agree with the distribution in the Southeastern Pacific (Galapagos Islands and Cocos Island) at depths below $100 \mathrm{~m}$ (H.L. Clark 1917). Consequently, it is plausible that Ziesenhenne's specimen does not correspond to $O$. pentacanthum but to a similar species (e.g., $O$. hendleri sp. nov.). Also, the Solís-Marín et al. (2013) record of O. pentacanthum from Guatemala is erroneous. Therefore, we suggest that the records from Mexico and Guatemala should be considered invalid. 
Ophioderma variegatum Lütken, 1856

Figs 8-9; Table 1

Ophioderma variegata Lütken, 1856: 21.

Ophioderma variegata - Lütken 1859: 199. — Lütken \& Mortensen 1899: 100-101, pl. 1, figs 1-3. Koehler 1907: 282; 1914: 7. — H.L. Clark 1913: 205. — Ziesenhenne 1955: 198. — Luke 1982: 33. - Granja-Fernández et al. 2015a: 41; 2015b: 95.

Ophiura variegata - Verrill 1867: 254. — Lyman 1875: 3; 1882: 10.

Ophioderma variegatum - H.L. Clark 1915: 302, pl. 18, figs. 7-8; 1940: 343. — Nielsen 1932: 330332, fig. 36. - Boone 1933: 114-115, pl. 67. — Ziesenhenne 1937: 227. — Maluf 1988: 84, 203. — Solís-Marín et al. 2005: 128; 2013: 570. — Honey-Escandón et al. 2008: 63. — Alvarado et al. 2010: 48.

\section{Diagnosis}

Radial shields covered by granules. Base of the arms and distal genital slits with granulation. First ventral arm plate large, broader than long. Oral shields oval, larger than broad, proximal margin rounded with an obtuse angle, distal edge convex, lateral margins straight. Naked adoral shields, longer than broad. Up to 9 arm spines, very large and slender; dorsalmost and ventralmost a little bit shorter than the rest. In vivo coloration: dorsal disc olive-green with dark pink or red; arms with transverse olive-green and dark pink-red bands.

\section{Examined material}

Lectotype (here designated)

NICARAGUA• 1 spec.; Realejo; 9.1 m (5 fathoms); NHMD-107680.

Paralectotypes (here designated)

NICARAGUA • 2 specs; same collection data as for lectotype; NHMD-619214.

\section{Designation of lectotype and paralectotype}

In the original description of Ophioderma variegatum, Lütken (1856) only mentioned the existence of one uncatalogued specimen ( $\mathrm{DD}=14 \mathrm{~mm}$ ) as part of the type material. However, three specimens are present in this lot (pers. com. Schiøtte, 2019) all of similar size (DD $=\sim 12.5 \mathrm{~mm}$ ). The similarities of the morphological characters and sizes make it impossible to determine which of them corresponds to the specimen described by Lütken (1856). There are some discrepancies between the measurements from Lütken (1856) and our measurements which could be due to the preservation of the specimens through time. Because of this, and according to Recommendation $73 \mathrm{~F}$ of the International Code of Zoological Nomenclature (ICZN 1999), we propose the designation of the specimen NHMD-107680 as the lectotype and NHMD-619214 contains the paralectotypes (two specimens) for $O$. variegatum.

\section{Other material}

See: Supplementary material.

\section{Description (Lectotype)}

$\mathrm{DD}=12.4 \mathrm{~mm} ; 5 \mathrm{arms}, \mathrm{AL}=62 \mathrm{~mm}$. Disc flat and rounded. Dorsal disc densely covered by rounded and very small granules, granule density $222 \mathrm{~mm}^{-2}$; granules extend to base of arms. Some granules rubbed off in some areas of disc. Radial shields covered by granules (rubbed off in some parts due to preservation) (Fig. 8A). Interradii covered with granules, similar to those on dorsal disc (Fig. 8B). Four genital slits on each interradius; proximal genital slits elongated and shorter than distal slits, in 
contact with distal part of oral shield and with first LAP; distal genital slits elongated and surrounded by granulation (Fig. 8B).

Oral shields longer than broad, oval, proximal margin convex obtuse angled, distal edge convex, lateral margins straight. Madreporite with a small, circular and shallow depression located in center of oral shield. Adoral shields naked, triangular, longer than broad, separated. Jaws bear 8-9 papillae on each side: LyOs very small, as long as broad, angled upwards; AdShSp largest, rounded; $2^{\circ} \mathrm{AdShSp}$ smaller but similar in shape to AdShSp; LOPa 4-5 conical, pointed and separated, $1^{\text {st }} \mathrm{LOPa}$ similar in shape to and smaller than $2^{\circ} \mathrm{AdShSp}$; IPa sometimes large, elongated, pointed and separated; TPa 2 at jaw tips, larger than $\mathrm{LOPa}$, elongated, robust and pointed, separated. Granules covering oral plates slightly longer than those on dorsal disc and interradii (Fig. 8C).

Dorsal base of arms with granules. Dorsal arm plates, $2 \times$ broader than long, trapezoidal, overlapping (Fig. 8D). First ventral arm plate large, broader than long, oval (Fig. 8C). Subsequent ventral arm plates quadrangular, slightly broader than long; distal edge slightly concave (Fig. 8E). Paired, rounded, and very small holes between $1^{\text {st }}$ and $2^{\text {nd }}$, and $2^{\text {nd }}$ and $3^{\text {rd }}$ ventral arm plates (Fig. 8B-C). LAP with up to 7-8 arm spines. Arm spines with a blunt tip, slender, and very large. All arm spines of almost same size except dorsalmost and ventralmost, which are just a little shortest than rest (Fig. 8E); length approximately $2 / 3$ of size of LAP. Tentacle scales 2; adradial tentacle scale ovoid, elongated; abradial tentacle scale slightly shorter, subtriangular (Fig. 8E).

Specimen (ethanol preservation) discolored but with a disc with different shades of brown and arms with transverse dark brown bands (Fig. 8F).

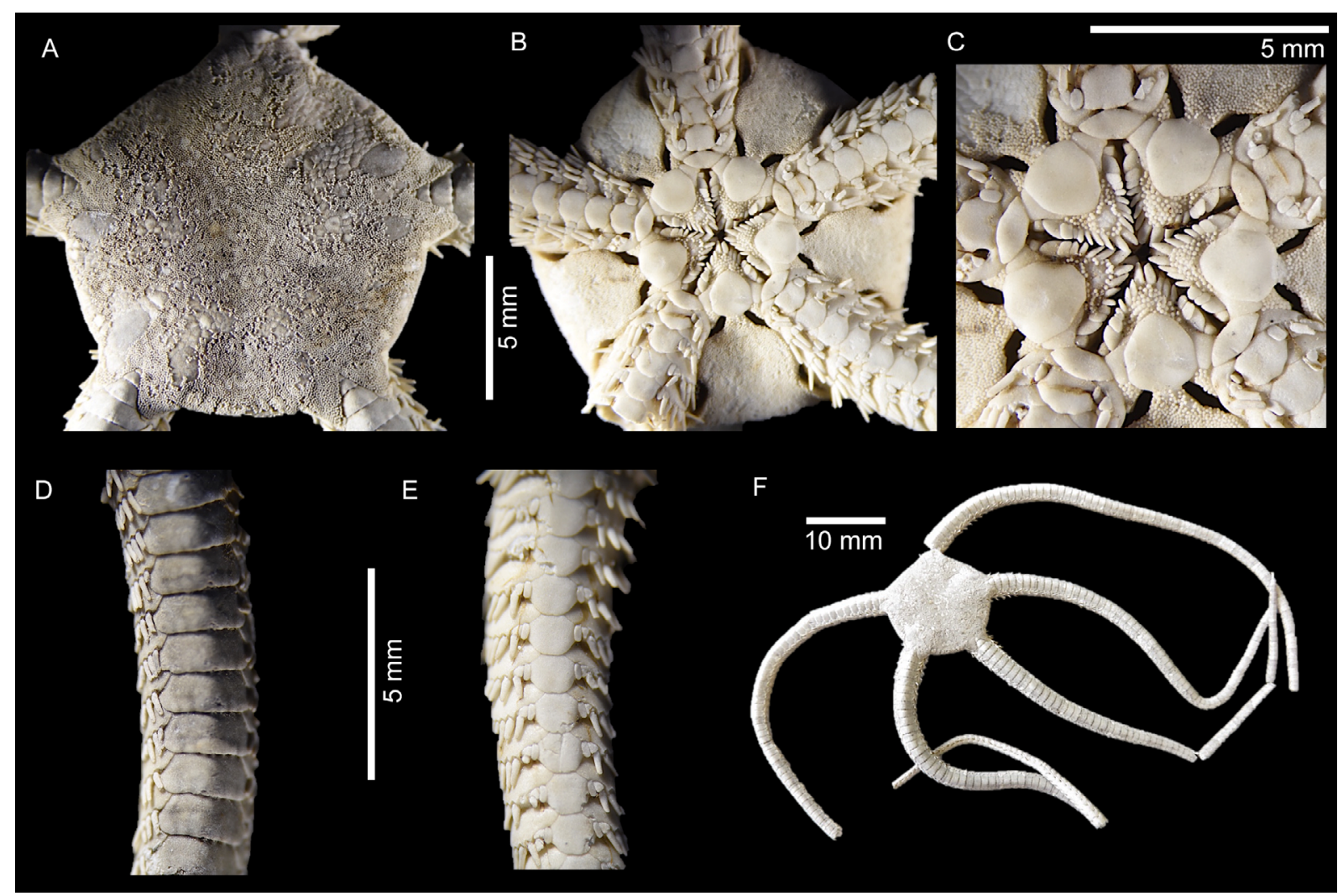

Fig. 8. Ophioderma variegatum Lütken, 1856, lectotype (NHMD-107680, DD =12.4 mm). A. Dorsal disc. B. Ventral disc. C. Mouth. D. Dorsal arm. E. Ventral arm. F. Dorsal view. 

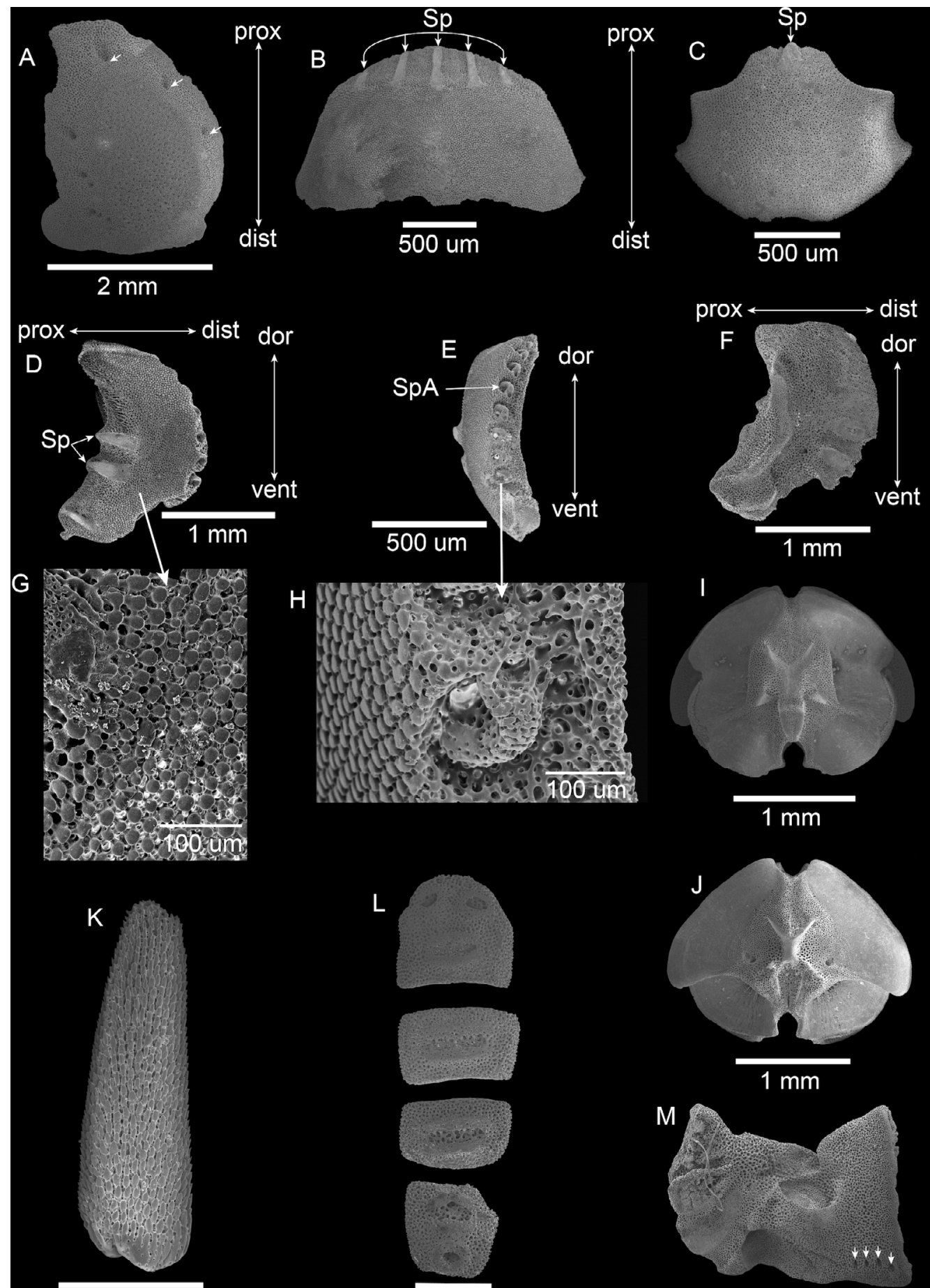

$1 \mathrm{~mm}$

300 um
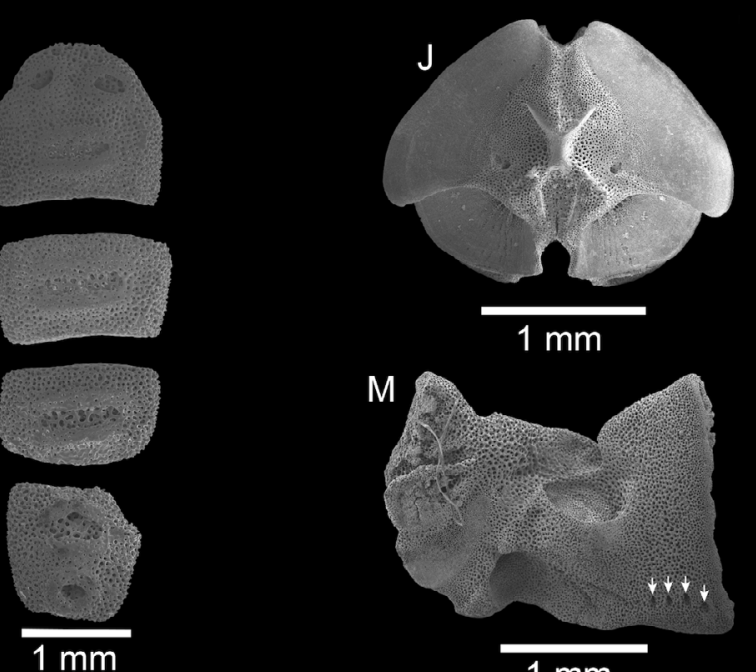

$1 \mathrm{~mm}$

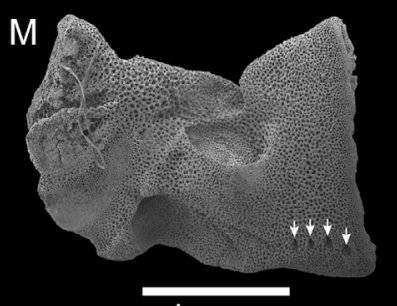

Fig. 9. SEM images of skeletal elements of Ophioderma variegatum (ICML-UNAM 3.20.4, DD = $13.6 \mathrm{~mm}$ ). A. Radial shield (external view), deepest pores marked with arrows. B. Dorsal arm plate, with five spurs. C. Ventral arm plate, with one spur. D. Lateral arm plate, external face, with two spurs and one condyle. E. Lateral arm plate, lateral face, with spine articulations. F. Lateral arm plate, internal face. G. Outer surface of the LAP (D) with fine mesh and rounded knobs. H. Spine articulations with a weak sigmoidal fold and tilted lobes. I. Arm vertebra, distal face. J. Arm vertebra, proximal face. K. Arm spine. L. Dental plate fragments. M. Oral plate, adradial face, with arrows pointing to four oral papillae sockets. 


\section{Disarticulated ossicles}

Specimen analyzed: 1 spec., ICML-UNAM 3.20.4 (DD = $13.6 \mathrm{~mm}, \mathrm{AL}=66.5 \mathrm{~mm})$. Radial shield (external view) irregularly rounded, with an incised proximal margin, a slightly indented abradial edge with a tiny projection, a convex distal edge, and convex adradial margin, bordered by 9 pores along median to proximal margin (which are covered/overlapped by disc scales and granules in intact animal) (Fig. 9A). Dorsal arm plate arched and somewhat trapezoid-shaped, $2 \times$ as wide as long; proximal edge convex with 5 spurs on proximal portion of external surface, distally straight and incised (Fig. 9B). Ventral arm plate $2 \times$ as wide as long, rectangular-shaped with proximal side truncated and with a pointed-shape spur, lateral sides concave forming border of tentacle pore, distal margin convex (Fig. 9C). LAP D-shaped, $2 \times$ as high as wide, with 9 spine articulations sunken in notches of distal edge (Fig. 9D-E). Ventral portion of LAP projecting ventro-proximalwards (Fig. 9D). Proximal edge of LAP with 2 prominent and elongated spurs, which are protruding and modify central-proximal edge (Fig. 9D), between spurs and across remaining proximal margin a discernible band of different stereom structure is present (Fig. 9D). Outer surface finely meshed with rounded stereom knobs (Fig. 9G). Inner surface of LAP with a continuous prominent ridge on proximal edge (see arched view) and on ventrodistal margin 2 spurs matching those on external surface, with 1 perforation on vertical furrow (Fig. 9F). Spine articulations ventralwards increasing in size (Fig. 9E). Lobes with a weak sigmoidal fold, tilted, and curved (Fig. 9H). Ventral lobe less conspicuous than dorsal lobe (Fig. 9H). Proximal vertebrae with a wing-like muscle flange (Fig. 9J). Distal face of vertebrae almost round, as wide as long, with large and irregular (sinuous) aboral muscle flange, with typical zygospondylous articulation (Fig. 9I). Spines with a scale-like surface, a blunt tip and laterally flattened (Fig. 9K). Dental plate consists of several pieces, $1^{\text {st }}$ piece has $2 \mathrm{TPa}$ and 1 wide tooth, while rest of pieces with 1 tooth socket per piece ( 5 in total), none of sockets penetrate plate (Fig. 9L). Oral plate as long as high, adradial plate with a less indented middle section, and 4 oral papillae sockets (Fig. 9M).

\section{Habitat and distribution}

USA (California), Mexico (Baja California, Gulf of California, Jalisco, Oaxaca, Isabel Island, Revillagigedo Islands, Marías Islands), Nicaragua, Costa Rica (Cocos Island), Panama (Pearl Islands) and Galapagos Islands. From intertidal zone to $110 \mathrm{~m}$ depth. Collected in sand, rock, rubble, coral, algae, shell, oysters, and mangrove leaves (Ziesenhenne 1937; Clark 1940; Maluf 1988; Solís-Marín et al. 2013; Granja-Fernández et al. 2015a).

\section{Remarks}

In the original description of $O$. variegatum, Lütken (1856) provided just a brief description, but later he extended it (Lütken, 1859). However, the description provided in the present work is the most complete to date. All the characters mentioned by Lütken $(1856,1859)$ correspond with the lectotype and paralectotype designated in this work. Although the type specimens are discolored, many authors (Lütken 1859; Verrill 1867; Lütken \& Mortensen 1899; H.L. Clark 1913, 1940; Koehler 1914; Boone 1933) and our present work coincide that the coloration of this species consists of an olive-green disc with irregular blotches of bright rose-red and the arms banded with lighter and darker grayish green, brown or white every two to five dorsal segments.

Although $O$. variegatum and $O$. panamense are completely different in overall morphology (Table 1), during our revisions we observed that it is very common to find specimens of $O$. variegatum identified as O. panamense, and vice versa. This tendency is very common in some published works (see references below); for example, we detected that in the description (i.e., naked radial shields and covered adoral shields) as well as the images of the species by Caso $(1951,1962,1979,1986)$, the specimens identified as $O$. variegatum were misidentified and corresponded to $O$. panamense. All the specimens studied by Caso are deposited at ICML-UNAM, and this identity was corroborated (see: Supplementary material). It is very feasible that the material mentioned in Caso et al. (1996) also corresponds to O. panamense, 
but neither a description nor images of the studied specimens are provided in this work and therefore we cannot confirm it.

The jaw of the type material of $O$. variegatum was closed, but like the other species of Ophioderma, voucher specimens with open jaws have one large and pointed OPRSp on each side, visible within the buccal cavity. It is important to recall that OPRSp were previously mentioned as spiniform structures or as a conspicuous pointed papilla (e.g., H.L. Clark 1917). Hendler (2018) coined the term suggesting that OPRSp in Ophioderma (along with OPa and teeth) are used to grip food between the closed jaws and to retain items in the buccal cavity, facilitating a feeding habit of predation and scavenging.

According to our study, $O$. variegatum is less abundant and less conspicuous in rock and coral reef zones of the Eastern Pacific compared to $O$. panamense. Ophioderma variegatum tends to inhabit deeper areas (up to $110 \mathrm{~m}$ ) and it is commonly collected by dredging, whereas $O$. panamense is easily collected by hand in shallow waters (up to $20 \mathrm{~m}$ depth).

Maluf \& Brusca (2005) reported O. variegatum for Gorgona Island (Colombia) but without any supporting data; therefore, we suspect that this record is invalid. Nevertheless, due to the wide geographic distribution of the species, it is very plausible to find it in Colombia (or even further south), but specimens are needed to confirm this record.

\section{Discussion}

Previously, a total of seven valid Ophioderma species (O. panamense, O. pentacanthum, O. peruanum, $O$. sodipallaresi, $O$. teres, $O$. vansyoci, and $O$. variegatum) and one species with unclear taxonomic status (O. teres var. unicolor) were reported for the Eastern Pacific (Lütken 1856, 1859; Lyman 1860; H.L. Clark 1917, 1940; Caso 1986; Hendler 1996; Pineda-Enríquez et al. 2013) but with the contribution of the new species $O$. hendleri sp. nov., the number increases to nine. These Ophioderma can be separated in two groups: species with adoral shields covered by granules $(O$. panamense, $O$. peruanum, $O$. sodipallaresi, $O$. teres, $O$. teres var. unicolor, $O$. vansyoci) and species with naked adoral shields (O. hendleri sp. nov., O. pentacanthum, O. variegatum). Although the group of Ophioderma with naked adoral shields consists of just three species, they have frequently been confused among each other and with the conspicuous $O$. panamense (with covered adoral shields). In this regard, 1) $O$. hendleri sp. nov. has been misidentified as $O$. variegatum or $O$. panamense, 2) $O$. panamense as $O$. teres or $O$. variegatum, and 3) $O$. variegatum as $O$. panamense. Despite the above, the revision of the type material and voucher specimens reveals that all these species are different in morphology (Table 1).

One of the most common Ophioderma in the Eastern Pacific, along with $O$. hendleri sp. nov., is $O$. panamense and the misidentification between both species could be due to sympatry (Mexico, Costa Rica and Panama) and because they share similar bathymetrical ranges (intertidal to approximately $40 \mathrm{~m}$ ) and habitats (rocky and coral reefs) (Granja-Fernández et al. 2014). Ophioderma hendleri sp. nov. cannot be morphologically confused with $O$. panamense because the latter species has naked radial shields as well as adoral shields covered by granules (Table 1). On the other hand, the confusion between $O$. hendleri sp. nov. and $O$. variegatum is more reasonable since both species have radial shields covered by granules and naked adoral shields; nevertheless, they have significant different morphological characters like the number, shape, and length of the arm-spines, the shape of oral and adoral shields, and the coloration (Table 1; Granja-Fernández et al. 2014).

It is important to note that $O$. hendleri sp. nov. is more closely related to $O$. pentacanthum than the rest of the species, and they can be differentiated by 1) up to $11 \mathrm{arm}$ spines in $O$. hendleri sp. nov. and up to six in $O$. pentacanthum, the ventralmost being much larger than the rest; 2) adradial tentacle scale slightly larger than abradial in $O$. hendleri sp. nov., but in $O$. pentacanthum the adradial tentacle scale is much 
larger; 3) short and rounded genital slits in $O$. hendleri sp. nov. and large and slender in O. pentacanthum; and finally, 4) $O$. hendleri sp. nov. is distributed in shallow waters and $O$. pentacanthum in deeper waters (Table 1).

The mix-up of $O$. panamense with other Ophioderma was very common in all the scientific collections. The main differences between $O$. panamense and $O$. teres can be consulted in Granja-Fernández et al. (2014). Ophioderma panamense can be distinguished from $O$. variegatum by: 1) naked radial shields versus radial shields covered by granules, respectively; 2) base of the arms and distal genital slits covered by granules and scales in $O$. panamense but only covered by granules in $O$. variegatum; 3 ) arm-spines shorter and robust versus very large and thin in O. variegatum; 4) oral shields broader than long and rounded versus longer than broad and oval in $O$. variegatum; 5) covered adoral shields versus naked in $O$. variegatum; and, 6) O. panamense occurs in shallower depths than O. variegatum (Table 1).

We attribute the persistent confusion of the species of Ophioderma from the Eastern Pacific to their cryptic diversity, but mostly to a lack of the study and comparison of the type materials. Moreover, the material of some species (e.g., O. pentacanthum) is scarce which impedes the improvement of their knowledge. During this work, the collection of more specimens and the study of the type material allowed us to expand the known geographical distribution range of $O$. pentacanthum (from Galapagos Islands, Ecuador to Cocos Island, Costa Rica) as well as to find the new species $O$. hendleri sp. nov. and with this discovery, the total number of valid species of Ophioderma in the world increases to 33.

Along with Ophiactis, Ophiocoma, Ophiocomella, Ophionereis, and Ophiothrix, Ophioderma is one of the most conspicuous genera of ophiuroids, with the greatest number of species in shallow rocky and coral reefs of the Eastern Pacific. Despite the above, this work reveals that there is much work to do with the taxonomy of Ophioderma because its morphology is often confused, and with the use of molecular markers it will highly increase our knowledge, as it has previously been noted that Ophioderma has clear examples of cryptic speciation (Stöhr et al. 2020b). Also, it is important to investigate the reproductive seasonality of the species from the Eastern Pacific, as well as their dispersal mechanisms to understand their geographic ranges. In this work we focus on the Ophioderma with naked adoral shields (besides $O$. panamense) but it is of importance to provide a further work of the species with covered adoral shields to complete the analysis of Ophioderma of the Eastern Pacific.

\section{Acknowledgements}

We wish to express our sincere gratitude to Yuri Hooker (CZA); Mercedes Cordero and Michel Hendrickx (EMU-UNAM); Alicia Durán-González, Ma. Esther Diupotex, Itzel Contreras and Daniel Mireles (ICML-UNAM); Berenit Mendoza (IB-UNAM); Patricia Salazar-Silva (ITBB); Gordon Hendler and Cathy Groves (LACM); David Pawson, Penny Benson and Adam Baldinger (MCZ); Karla Humara, Universidad de Guadalajara (UdG); Rosa Sotelo-Casas, Universidad Nacional Autónoma de México (UNAM); Erika Montoya and Giomar Borrero (MHNMC-Makuriwa); David Pawson, Chad Walter, Geoff Keel, Jon Nurenburg and Paul Greenhall (USNM); Leonardo Chacón and Juan José Alvarado (MZUCR) and, Tom Schiøtte and Jørgen Oelsen (NHMD) for providing their invaluable support during the collections visits. We thank Alejandra Hernández and Sabine Stöhr for their invaluable support in taxonomy and discussion of some characters. To Andrés López, David Paz, Alejandro Hernández, Diego Rangel, Leonardo Chacón, Paola Rodríguez, Braulio Martínez, Rosa Sotelo, Omar Valencia, Adolfo Tortolero and Luis Hernández we are thankfull for helping in the collection of the specimens. This study was funded by Comisión Nacional para el Conocimiento y Uso de la Biodiversidad (JF047, HJ029), Fondo de Investigación Científica Básica del Consejo Nacional de Ciencia y Tecnología (236654), and Convocatoria Fronteras en la Ciencia del Consejo Nacional de Ciencia y Tecnología (Project 292). This work is part of the post-doc of RGF at UdG PRODEP 511-6/2019.-12278, and was supported by CONACYT 336853, an Ernst Mayr Grant (MCZ) and a grant by Plataforma de Movilidad Estudiantil y 
Académica de la Alianza del Pacífico, Programa Nacional de Becas y Crédito Educativo (PRONABECPeru) granted to RGF. We thank the EJT editing team, T. O'Hara and an anonymous reviewer for their thoughtful and detailed comments which helped improve this manuscript.

\section{References}

Alvarado J.J., Solís-Marín F.A. \& Ahearn C.G. 2010. Echinoderm (Echinodermata) diversity in the Pacific coast of Central America. Marine Biodiversity 40: 45-56.

https://doi.org/10.1007/s12526-009-0032-5

Bastida-Zavala J.R., García-Madrigal M.S., Rosas-Alquicira E.F., López-Pérez R.A., Benítez-Villalobos F., Meraz-Hernando J.F., Torres-Huerta A.M., Montoya-Márquez A. \& Barrientos-Luján N.A. 2013. Marine and coastal biodiversity of Oaxaca, Mexico. Check List 9 (2): 329-390. https://doi.org/10.15560/9.2.329

Boissin E., Stöhr S. \& Chenuil A. 2011. Did vicariance and adaptation drive cryptic speciation and evolution of brooding in Ophioderma longicauda (Echinodermata: Ophiuroidea), a common AtlantoMediterranean ophiuroid? Molecular Ecology 2: 4737-4755. https://doi.org/10.1111/j.1365-294X.2011.05309.x

Boolotian R.A. \& Leighton D. 1966. A key to the species of Ophiuroidea (brittle stars) of the Santa Monica Bay and adjacent areas. Los Angeles County Museum Contributions in Science 93: 1-20.

Boone L. 1933. Scientific results of cruises of the yachts "Eagle" and "Ara", 1921-1928, William K. Vanderbilt, commanding. Coelenterata, Echinodermata and Mollusca. Bulletin of the Vanderbilt Marine Museum 4: 1-217.

Buitrón-Sánchez B.E. \& Solís-Marín F.A. 1993. La biodiversidad en los equinodermos fósiles y recientes de Mexico. Revista de la Sociedad Mexicana de Historia Natural 64: 209-231.

Campbell A.S. 1921. Littoral ophiurans at Laguna Beach. Journal of Entomology and Zoology 13: 2-4.

Caso M.E. 1951. Contribución al conocimiento de los ofiuroideos de Mexico. 1. Algunas especies de ofiuroideos litorales. Anales del Instituto de Biología, Universidad Nacional Autónoma de Mexico 22 (1): 219-312.

Caso M.E. 1962. Estudios sobre equinodermos de México. Contribución al conocimiento de los equinodermos de la Islas Revillagigedo. Anales del Instituto de Biología, Universidad Nacional Autónoma de Mexico 33 (1-2): 293-330.

Caso M.E. 1979. Los equinodermos de la Bahía de Mazatlán, Sinaloa. Anales del Centro de Ciencias del Mar y Limnología, Universidad Nacional Autónoma de Mexico 6 (1): 197-368.

Caso M.E. 1986. Descripción de una nueva especie de ofiuroideo de la Bahía de Mazatlán, Sin. Ophioderma sodipallaresi sp. nov. y comparación con Ophioderma variegatum Lütken. Anales del Centro de Ciencias del Mar y Limnología, Universidad Nacional Autónoma de Mexico 13 (2): 223-248.

Caso M.E., Laguarda-Figueras A., Solís-Marín F.A., Ortega-Salas A. \& Durán-González A.L. 1996. Contribución al conocimiento de la ecología de las comunidades de equinodermos de la Bahía de Mazatlán, Sinaloa, Mexico. Anales del Instituto de Ciencias del Mar y Limnología, Universidad Nacional Autónoma de México 22 (1): 101-120.

Clark H.L. 1913. Echinoderms from Lower California, with descriptions of new species. Bulletin of the American Museum of Natural History 32: 185-236. https://doi.org/10.5962/bhl.title.1734

Clark H.L. 1915. Catalogue of recent ophiurans: based on the collection of the Museum of Comparative Zoölogy. Memoirs of the Museum of Comparative Zoölogy 25 (4): 164-376.

https://doi.org/10.5962/bhl.title.48598 
Clark H.L. 1917. Reports on the scientific results of the expedition to the Eastern Tropical Pacific in charge of Alexander Agassiz, by the U.S. Fish Commission Steamer Albatross from October, 1904, to March, 1905, Lieut. Commander L.M. Garrett, U.S.N., Commanding. XXX. Ophiuroidea. Bulletin of the Museum of Comparative Zoology at Harvard College 61 (12): 429-453.

Clark H.L. 1940. XXI. Notes on Echinoderms from the west coast of Central America. Eastern Pacific Expeditions of the New York Zoological Society. Zoologica 25 (22): 331-352.

Cortés J. 2012. Marine biodiversity of an Eastern Tropical Pacific oceanic island, Isla del Coco, Costa Rica. Revista de Biología Tropical 60 (3): 131-185. https://doi.org/10.15517/RBT.V60I3.28356

Downey M.E. 1969. Catalog of recent ophiuroid type specimens in major collections in the United States. United States National Museum Bulletin 293: 1-239. https://doi.org/10.5479/si.03629236.293

Granja-Fernández M.R. \& López-Pérez R.A. 2012. Biodiversidad de ofiuroideos (Echinodermata: Ophiuroidea) de Oaxaca y Chiapas. In: Sánchez A.J., Chiappa-Carrara X. \& Brito-Pérez R. (eds) Recursos Costeros del Sureste: Tendencias actuales en Investigación y Estado del Arte: 357-370. CONCITEY, FOMIX, SIIDETEY, UNAM, CONACYT, ECOSUR, PROMEP, RECORECOS, UNACAR, UJAT, Mérida.

Granja-Fernández R. \& Hooker Y. 2020. Revisiting the diversity and distribution of the ophiuroids (Echinodermata: Ophiuroidea) from Peru. Zootaxa 4766 (4): 539-556.

https://doi.org/10.11646/zootaxa.4766.4.2

Granja-Fernández R., Herrero-Pérezrul M.D., López-Pérez R.A., Hernández L., Rodríguez-Zaragoza F.A., Jones R.W. \& Pineda-López R. 2014. Ophiuroidea (Echinodermata) from coral reefs in the Mexican Pacific. Zookeys 406: 101-145. https://doi.org/10.3897/zookeys.406.6306

Granja-Fernández R., Herrero-Pérezrul M.D., López-Pérez A., Hernández-Morales A. \& Rangel-Solís P.D. 2015a. A literature review of the Ophiuroidea (Echinodermata) from the Pacific coast of Mexico. Revista de Biología Tropical 63 (2): 37-47. https://doi.org/10.15517/RBT.V63I2.23127

Granja-Fernández R., Solís-Marín F.A., Benítez-Villalobos F., Herrero-Pérezrul M.D. \& López-Pérez A. 2015b. Checklist of echinoderms (Echinodermata) from the Southern Mexican Pacific: a historical review. Revista de Biología Tropical 63 (2): 87-114. https://doi.org/10.15517/rbt.v63i2.23131

Granja-Fernández R., Rodríguez-Troncoso A.P., Herrero-Pérezrul M.D., Sotelo-Casas R.C., FloresOrtega J.R., Godínez-Domínguez E., Salazar-Silva P., Alarcón-Ortega L.C., Cázares-Salazar A. \& Cupul-Magaña A.L. 2017. Ophiuroidea (Echinodermata) from the Central Mexican Pacific: an updated checklist including new distribution records. Marine Biodiversity 47: 167-177.

https://doi.org/10.1007/s12526-016-0459-4

Hendler G. 1996. Echinodermata collected at Rocas Alijos. In: Schmieder R.W. (ed.) Rocas Alijos. Scientific Results from the Cordell Expeditions: 319-338. Springer, Dordrecht, Netherlands. https://doi.org/10.1007/978-94-017-2917-8_27

Hendler G. 2018. Armed to the teeth: a new paradigm for the buccal skeleton of brittle stars (Echinodermata: Ophiuroidea). Contributions in Science 526: 189-311.

Hendler G., Miller J.E., Pawson D.L. \& Kier P.M. 1995. Sea Stars, Sea Urchins, and Allies. Echinoderms of Florida and the Caribbean. Smithsonian Institution, Washington.

Hernández-Herrejón L.A., Solís-Marín F.A., Laguarda-Figueras A. \& Pineda-Enríquez T. 2010. First record of Ophioderma vansyoci (Echinodermata: Ophiuroidea) in the Gulf of California. Marine Biodiversity Records 3 (e114): 1-3. https://doi.org/10.1017/S1755267210001028

Hickman C.P. 1998. A Field Guide to Sea Stars and other Echinoderms of Galápagos. Sugar Spring Press, Lexington, VA. 
Honey-Escandón M., Solís-Marín F.A. \& Laguarda-Figueras A. 2008. Equinodermos (Echinodermata) del Pacífico Mexicano. Revista de Biología Tropical 56 (3): 57-73.

https://doi.org/10.15517/RBT.V56I3.27079

ICZN, International Commission on Zoological Nomenclature. 1999. International Code of Zoological Nomenclature. Available from

https://www.iczn.org/the-code/the-international-code-of-zoological-nomenclature/the-code-online/ [accessed 1 Feb. 2020].

Ives J.E. 1889a. Variation in Ophiura panamensis and Ophiura teres. Proceedings of the Academy of Natural Sciences of Philadelphia 41: 76-77.

Ives J.E. 1889b. Catalogue of the Asteroidea and Ophiuroidea in the Collection of the Academy of Natural Sciences of Philadelphia. Proceedings of the Academy of Natural Sciences of Philadelphia 41: $169-179$.

Koehler R. 1907. Revision de la collection des ophiures du Museum D'Histoire Naturelle de Paris. Bulletin Scientifique de la France et de la Belgique 61: 279-370.

Koehler R. 1914. A contribution to the study of ophiurans of the United States National Museum. Bulletin of the United States National Museum 84: 1-173. https://doi.org/10.5962/bhl.title.27414

Luke S.R. 1982. Catalog of the Benthic Invertebrate Collections of the SCRIPPS Institution of Oceanography, Echinodermata. SCRIPPS Institution of Oceanography Reference Series, no. 82-5, University of California, San Diego. CA.

Lütken C.F. 1856. III. Bidrag til Kundskab om Ophiurerne ved Central-Amerikas Vestkyst. Videnskabelige Meddelelser fra Dansk Naturhistorisk Forening 1856: 20-26.

Lütken C.F. 1859. Additamenta ad Historiam Ophiuridarum. Beskrivelser af de fra Vestindien og Central Amerikas Vestkyst hidtil beckjendte Slangestjerner. Kongelige Danske Videnskabernes Selskab Biologiske Skrifter 2: 75-169.

Lütken C.F. \& Mortensen T. 1899. Reports on an exploration off the west coast of Mexico, central and South America, and off the Galapagos Islands, in charge of Alexander Agassiz, by the U.S. Fish Commission Steamer "Albatross", during 1891, Lieut. Commander Z.L. Tanner, U.S.N., commanding. XXV. The Ophiuridae. Memoirs of the Museum of Comparative Zoölogy at Harvard College 23 (2): 93-208. https://doi.org/10.5962/bhl.title.65637

Lyman T. 1860. Descriptions of new Ophiuridae, belonging to the Smithsonian Institution and to the Museum of Comparative Zoology at Cambridge. Proceedings of the Boston Society of Natural History 7: 193-204, 252-262. https://doi.org/10.5962/bhl.part.4822

Lyman T. 1865. Ophiuridae and Astrophytidae. Illustrated Catalogue of the Museum of Comparative Zoology at Harvard College 1: 1-200.

Lyman T. 1875. II. Ophiuridae and Astrophytidae. Zoological results of the "Hassler" Expedition. Illustrated Catalogue of the Museum of Comparative Zoölogy at Harvard College 8: 1-34.

Lyman T. 1882. Report on the Ophiuroidea dredged by H.M.S. "Challenger" during the years $1873-$ 1876. Report of the Scientific Results of the Voyage of H.M.S. "Challenger" 1873-1876 5 (14): 1-386.

Maluf L.Y. 1988. Composition and distribution of the central Eastern Pacific echinoderms. Natural History Museum of Los Angeles County, Technical Report 2: 1-242.

Maluf L.Y. 1991. Echinoderm fauna of the Galápagos Islands. In: James M.J. (ed.) Galapagos Marine Invertebrates: Taxonomy, Biogeography, and Evolution in Darwin's Islands: 345-367. Plenum, New York. https://doi.org/10.1007/978-1-4899-0646-5_17 
Maluf L.Y. \& Brusca R.C. 2005. Chapter 18. Echinodermata. In: Hendrickx M.E., Brusca R.C. \& Findley L.T. (eds) A Distributional Checklist of the Macrofauna of the Gulf of California, Mexico. Part I. Invertebrates: 327-343. Arizona-Sonora Desert Museum, Tucson.

McClendon J.F. 1909. XXV. The ophiurans of the San Diego region. University of California Publications in Zoology 6 (3): 33-64.

Nielsen E. 1932. Ophiurans from the Gulf of Panama, California and the Strait of Georgia. Videnskabelige Meddelelser fra Dansk Naturhistorisk Forening 91: 241-346.

O'Hara T.D., Stöhr S., Hugall A.F., Thuy B. \& Martynov A. 2018. Morphological diagnoses of higher taxa in Ophiuroidea (Echinodermata) in support of a new classification. European Journal of Taxonomy 416: 1-35. https://doi.org/10.5852/ejt.2018.416

Pineda-Enríquez T., Solís-Marín F.A., Hooker Y. \& Laguarda-Figueras A. 2013. Ophioderma peruana, a new species of brittlestar (Echinodermata, Ophiuroidea, Ophiodermatidae) from the Peruvian coast. ZooKeys 357: 53-65. https://doi.org/10.3897/zookeys.357.6176

Solís-Marín F.A., Laguarda-Figueras A., Durán-González A., Ahearn C.G. \& Torres-Vega J. 2005. Equinodermos (Echinodermata) del Golfo de California, México. Revista de Biología Tropical 53 (3): 123-137. https://doi.org/10.15517/RBT.V53I3.26770

Solís-Marín F.A., Alvarado J.J., Abreu-Pérez M., Aguilera O., Alió J., Bacallado-Aránega J.J. \& Williams S.M. 2013. Appendix. In: Alvarado-Barrientos J.J. \& Solís-Marín F.A. (eds) Echinoderm Research and Diversity in Latin America: 543-658. Springer-Verlag, Berlin.

https://doi.org/10.1007/978-3-642-20051-9

Stöhr S., Boissin E. \& Chenuil A. 2009. Potential cryptic speciation in Mediterranean populations of Ophioderma (Echinodermata: Ophiuroidea). Zootaxa 2071 (1): 1-20.

https://doi.org/10.11646/zootaxa.2071.1.1

Stöhr S., O'Hara T.D. \& Thuy B. 2012. Global diversity of brittle stars (Echinodermata: Ophiuroidea). PLOS ONE 7 (3): e31940. https://doi.org/10.1371/journal.pone.0031940

Stöhr S., O’Hara T.D. \& Thuy B. 2020a. World Ophiuroidea database. Available from http://www.marinespecies.org/ophiuroidea [accessed 1 May 2020].

Stöhr S., Weber A.A., Boissin E. \& Chenuil A. 2020b. Resolving the Ophioderma longicauda (Echinodermata: Ophiuroidea) cryptic species complex: five sisters, three of them new. European Journal of Taxonomy 600: 1-37. https://doi.org/10.5852/ejt.2020.600

Thuy B. \& Stöhr S. 2016. A new morphological phylogeny of the Ophiuroidea (Echinodermata) accords with molecular evidence and renders microfossils accessible for cladistics. PLoS ONE 11 (5): e0156140. https://doi.org/10.1371/journal.pone.0156140

Tirado-Sánchez N., Chiriboga A., Ruiz D. \& Banks S. 2014. CDF Checklist of Galapagos echinoderms - FCD Lista de especies de equinodermos Galapagos. In: Bungartz F., Herrera H., Jaramillo P., Tirado N., Jiménez-Uzcátegui G., Ruiz D., Guézou A. \& Ziemmeck F. (eds) Charles Darwin Foundation Galapagos Species Checklist: 1-37. Charles Darwin Foundation, Puerto Ayora, Ecuador.

Verrill A.E. 1867. V. Notes on the Radiata in the Museum of Yale College, with descriptions of new genera and species. No. 2. Notes on the echinoderms of Panama and West Coast of America, with descriptions of new genera and species. Transactions of the Connecticut Academy of Arts and Sciences 1 (2): $251-322$.

Ziesenhenne F.C. 1937. The Templeton Crocker Expedition. X. Echinoderms from the west coast of Lower California, the Gulf of California and Clarion Island. Zoologica 22 (15): 209-239. 
Ziesenhenne F.C. 1955. A review of the genus Ophioderma Müller and Troschel. In: Allan Hancock Foundation for Scientific Research (eds) Essays in the Natural Sciences in Honor of Captain Allan Hancock: 185-201. University of Southern California Press, Los Angeles.

Manuscript received: 20 May 2020

Manuscript accepted: 24 September 2020

Published on: 14 December 2020

Topic editor: Rudy Jocqué

Section editor: Didier VandenSpiegel

Desk editor: Jeroen Venderickx

Printed versions of all papers are also deposited in the libraries of the institutes that are members of the EJT consortium: Muséum national d'histoire naturelle, Paris, France; Meise Botanic Garden, Belgium; Royal Museum for Central Africa, Tervuren, Belgium; Royal Belgian Institute of Natural Sciences, Brussels, Belgium; Natural History Museum of Denmark, Copenhagen, Denmark; Naturalis Biodiversity Center, Leiden, the Netherlands; Museo Nacional de Ciencias Naturales-CSIC, Madrid, Spain; Real Jardín Botánico de Madrid CSIC, Spain; Zoological Research Museum Alexander Koenig, Bonn, Germany; National Museum, Prague, Czech Republic.

\section{Supplementary material}

Supplementary file 1: Examined material of Ophioderma species. https://doi.org/10.5852/ejt.2020.729.1187.3323 